\title{
Iodinated Meroditerpenes from a Red Alga Callophycus sp.
}

Serge Lavoie, ${ }^{\dagger, \downarrow}$ David Brumley, ${ }^{\dagger}$ Troy S. Alexander,${ }^{\dagger}$ Christine Jasmin, ${ }^{\dagger,}$ Franz A. Carranza, Kate Nelson, ${ }^{\S}$ Cassandra L. Quave, ${ }^{\S, \uparrow, \diamond}$ and Julia Kubanek ${ }^{\dagger, t, *}$

${ }^{\dagger}$ School of Chemistry and Biochemistry and ${ }^{\star}$ School of Biological Sciences, Aquatic Chemical Ecology Center, Institute for Bioengineering and Biosciences, Georgia Institute of Technology, Atlanta, Georgia 30332.

${ }^{\S}$ Department of Dermatology, ${ }^{\circledR}$ Center for the Study of Human Health, and ${ }^{\diamond}$ Antibiotic Resistance Center, Emory University, Atlanta, Georgia 30322

*julia.kubanek@biosci.gatech.edu 


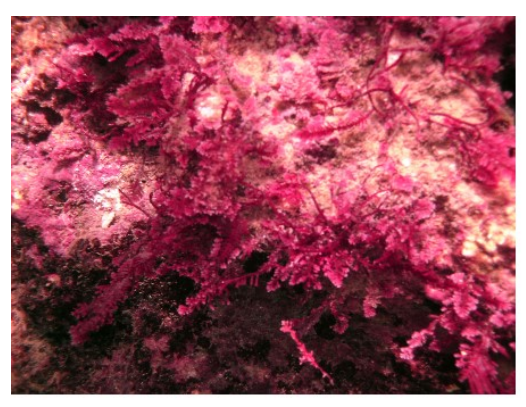

Callophycus sp.
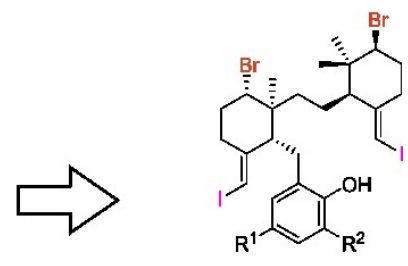

$1 \mathrm{COOH} H$

$2 \mathrm{Br} \quad \mathrm{Br}$

$3 \mathrm{Br} \quad \mathrm{I}$

$4 \mathrm{I} B \mathrm{Br}$

Unique iodine-containing meroditerpenes iodocallophycoic acid A (1) and iodocallophycols A-D (2-5) were discovered from the Fijian red alga Callophycus sp. Because flexibility of the molecular skeleton impaired full characterization of relative stereochemistries by NMR spectroscopy, a DFTbased theoretical model was developed to derive relevant inter-proton distances which were compared to those calculated from NOE measurements, yielding the relative stereochemistries. The correct $2 S, 6 S, 7 S, 10 S, 14 S$ enantiomers were then identified by comparison of theoretical and experimental ECD spectra. Biological activities of these iodinated and brominated meroditerpenes and additional new, related bromophycoic acid F (6) and bromophycoic acid A methyl ester (7), were evaluated for relevant human disease targets. Iodocallophycoic acid A (1) showed moderate antibiotic activity against methicillin-resistant Staphylococcus aureus (MRSA) and vancomycinresistant Enterococcus faecium (VREF) with MIC values of 1.4 and $2.2 \mu \mathrm{g} \mathrm{mL}^{-1}$, respectively. It also potentiated the anti-MRSA activity of oxacillin in a synergistic fashion, resulting in an 8-fold increase in oxacillin potency, for a MIC of $16 \mu \mathrm{g} \mathrm{mL}^{-1}$. 


\section{$\underline{\text { INTRODUCTION }}$}

Marine natural products are well known to incorporate halogen atoms such as chlorine, bromine, and iodine. ${ }^{1}$ The scientific literature suggests that iodine is far less prevalent than chlorine and bromine in secondary metabolites: of the 4700 halogenated chemicals inventoried in the Royal Society of Chemistry's MarinLit database, 1879 (40\%) included at least one chlorine atom, 3317 (71\%) contained bromine, but only 138 (3\%) incorporated iodine..$^{2}$ Taking into account the fact that chloride and bromide are 1 million and 2000-fold, respectively, more abundant than iodide in seawater, ${ }^{3,4}$ the number of iodinated compounds is actually disproportionately high in comparison to chlorinated and brominated compounds. Typically, halogens are enzymatically oxidized in order to be incorporated in the biosynthetic pathway of a secondary metabolite. ${ }^{5}$ Since iodide has a higher oxidation potential than bromide and chloride, ${ }^{6}$ it can be oxidized by haloperoxidases more readily which could explain this relatively high level of iodination among halogenated marine natural products.

Red algal secondary metabolites account for $30 \%$ of the known iodinated marine natural products. Most fall into one of three categories: low-molecular weight ketones (Figure S1), ${ }^{7-10}$ short-chain fatty acids, ${ }^{7,11,}$ 12 or furanone derivatives. ${ }^{13,14}$ Recently, bromo-chloro-iodoindoles from the red alga Rhodophyllis membranacea were reported as the first natural products containing three halogen types. ${ }^{15}$ Also, five terpenes iodinated at a terminal methylene or on a benzene ring have been described from red algae. ${ }^{16-18}$ Herein, we report the isolation and structural characterization of five new iodinated (and brominated) meroditerpenes (1-5), along with the determination of their absolute stereochemistries by quantitative NOESY, ECD spectroscopy, and DFT modeling. In addition, we report the structures of three other meroditerpenes 6-8 related to previously discovered Callophycus meroditerpenes, ${ }^{19}$ as well as their biological activities. 


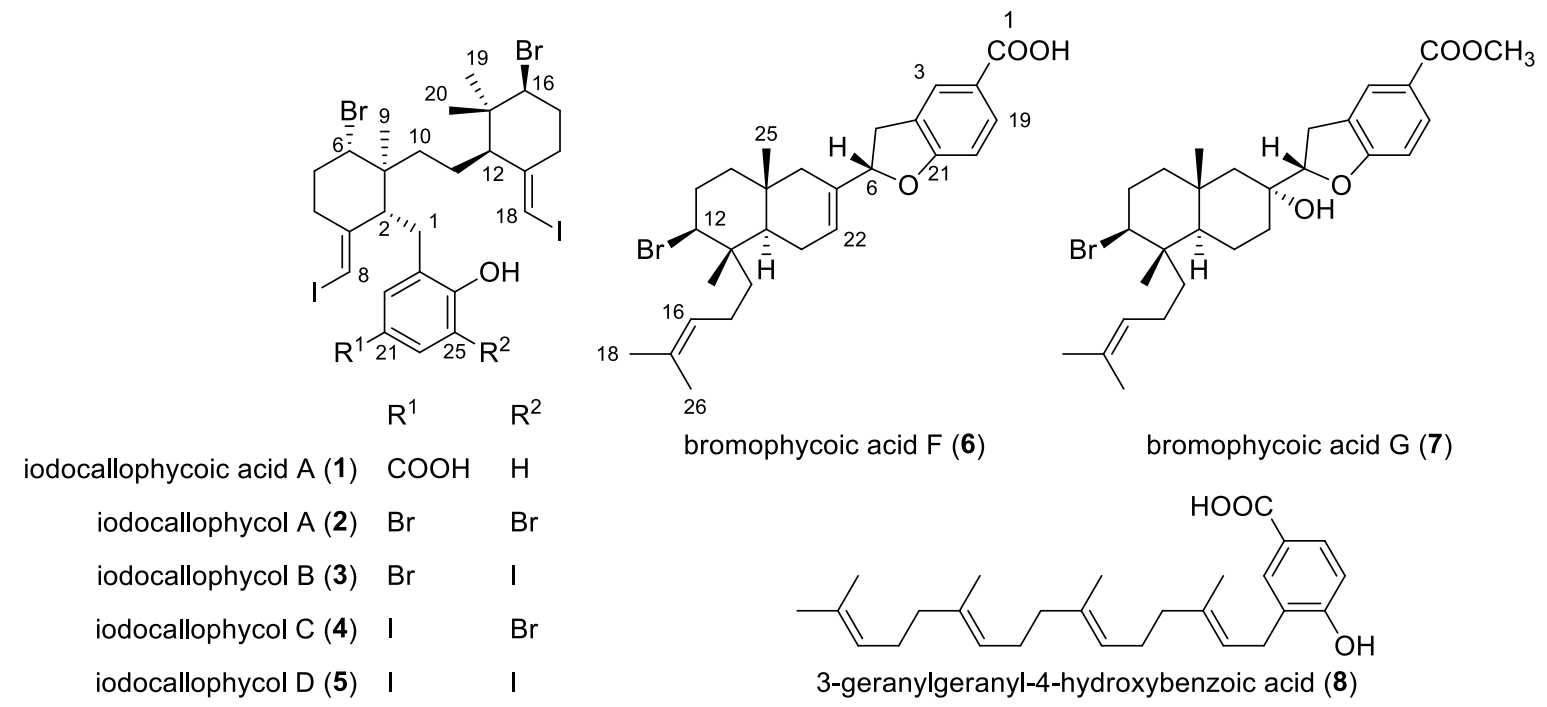

\section{RESULTS AND DISCUSSION}

Extracts of a red alga Callophycus sp. were fractionated by liquid-liquid partition, column chromatography, and reversed-phase HPLC, yielding pure 1-8. Compound $\mathbf{1}$ was isolated as a white amorphous solid. Its molecular formula was determined to be $\mathrm{C}_{27} \mathrm{H}_{34} \mathrm{Br}_{2} \mathrm{I}_{2} \mathrm{O}_{3}$ by HRESIMS $(m / z$ 816.8879, calcd for $\mathrm{C}_{27} \mathrm{H}_{33} \mathrm{Br}_{2} \mathrm{I}_{2} \mathrm{O}_{3}[\mathrm{M}-\mathrm{H}]^{-}$816.8891). The presence of two bromine atoms was further indicated by an isotopic peak intensity ratio of 1:2:1 for the molecular ion. Analysis of the ${ }^{1} \mathrm{H},{ }^{13} \mathrm{C}$, and HSQC NMR spectroscopic data (Tables 1-2) indicated that 1 possessed three methyls, seven aliphatic methylenes, four aliphatic methine, and three aromatic methines. Long-range and vicinal COSY correlations from H-6' to $\mathrm{H}-2^{\prime}$ and $\mathrm{H}-5^{\prime}$, along with HMBC correlations from $\mathrm{H}-2^{\prime}$ to $\mathrm{C}-1, \mathrm{C}-4^{\prime}$, and $\mathrm{C}-7^{\prime}$, and from $\mathrm{H}-5^{\prime}$ to $\mathrm{C}-1^{\prime}$ and C-3', revealed the presence of a 4-hydroxybenzoic acid ring substituted at the meta position (Figure 1). The bromine atoms were assigned at C- 6 and C-14, and the iodine atoms at C-16 and C-18, based on a comparison of the ${ }^{1} \mathrm{H}$ and ${ }^{13} \mathrm{C}$ chemical shift with similar compounds. ${ }^{20,21}$. Ring A was assigned by COSY correlations from $\mathrm{H}_{2}-1$ to $\mathrm{H}-2$, from $\mathrm{H}-6$ to $\mathrm{H}_{2}-5$, and from $\mathrm{H}_{2}-5$ to $\mathrm{H}_{2}-4$, as well as $\mathrm{HMBC}$ correlations from $\mathrm{H}_{3}-17$ to $\mathrm{C}-2$, C-6 and $\mathrm{C}-8$, and from $\mathrm{H}-16$ to $\mathrm{C}-2$ and C-4. Ring B was established by COSY correlations from $\mathrm{H}-14$ to $\mathrm{H}_{2}-13$, and from $\mathrm{H}_{2}-13$ to $\mathrm{H}_{2}-12$, along with $\mathrm{HMBC}$ correlations from $\mathrm{H}_{3}-19$ and $\mathrm{H}_{3}-20$ to $\mathrm{C}-14$ and $\mathrm{C}-10$, and from $\mathrm{H}-18$ to $\mathrm{C}-10$ and $\mathrm{C}-12$. Finally, the two rings were shown to 
connect to each other via an ethylene bridge by COSY correlations between $\mathrm{H}_{2}-8$ to $\mathrm{H}_{2}-9$, and between $\mathrm{H}_{2}-9$ and $\mathrm{H}_{2}-10$.

Table 1. ${ }^{1} \mathrm{H}$ NMR Spectroscopic Data $(800 \mathrm{MHz})$ of Iodocallophycoic Acid A (1) and Iodocallophycols $\mathrm{A}-\mathrm{D}(\mathbf{2}-\mathbf{5})$ in $\mathrm{CD}_{3} \mathrm{OD}$.

\begin{tabular}{|c|c|c|c|c|c|}
\hline \multirow{2}{*}{ position } & \multicolumn{5}{|c|}{$\delta_{\mathrm{H}}$ mult $(J \text { in } \mathrm{Hz})^{b}$} \\
\hline & 1 & 2 & 3 & 4 & 5 \\
\hline \multirow[t]{2}{*}{1} & $3.01 \mathrm{dd}(14.5,11.8)$ & $3.07 \mathrm{dd}(15.2,11.8)$ & $3.05 \mathrm{dd}(15.3,11.7)$ & $3.04 \mathrm{dd}(15.0,11.8)$ & $3.02 \mathrm{dd}(14.9,11.4)$ \\
\hline & 2.76 br d (14.3) & $2.78 \mathrm{dd}(15.2,2.9)$ & $2.78 \mathrm{dd}(15.3,2.7)$ & $2.76 \mathrm{dd}(15.3,2.8)$ & $2.77 \mathrm{~m}$ \\
\hline 2 & 2.97 br d (12.2) & 2.84 br d (12.4) & $2.83 \mathrm{~m}$ & $2.80 \mathrm{~m}$ & $2.79 \mathrm{~m}$ \\
\hline \multirow[t]{2}{*}{4} & $2.81 \mathrm{dt}(13.3,4.5)$ & $2.81 \mathrm{dt}(13.5,4.8)$ & $2.82 \mathrm{dt}(13.8,4.9)$ & $2.80 \mathrm{~m}$ & $2.81 \mathrm{dt}(13.5,4.9)$ \\
\hline & $2.13 \mathrm{~m}$ & $2.22 \mathrm{~m}$ & $2.21 \mathrm{~m}$ & $2.20 \mathrm{~m}$ & $2.21 \mathrm{~m}$ \\
\hline \multirow[t]{2}{*}{5} & $2.26 \mathrm{dq}(13.4,4.5)$ & $2.26 \mathrm{~m}$ & $2.26 \mathrm{~m}$ & $2.25 \mathrm{~m}$ & $2.26 \mathrm{~m}$ \\
\hline & $2.04 \mathrm{~m}$ & $2.06 \mathrm{~m}$ & $2.05 \mathrm{~m}$ & $2.05 \mathrm{~m}$ & $2.05 \mathrm{~m}$ \\
\hline 6 & $4.57 \mathrm{dd}(10.5,4.4)$ & $4.55 \mathrm{dd}(9.8,4.2)$ & $4.56 \mathrm{dd}(10.0,4.2)$ & $4.54 \mathrm{dd}(9.7,4.2)$ & $4.55 \mathrm{dd}(9.9,4.2)$ \\
\hline \multirow[t]{2}{*}{8} & $1.60 \mathrm{ddd}(14.5,11.8,5.2)$ & $1.51 \mathrm{~m}$ & $1.51 \mathrm{~m}$ & $1.50 \mathrm{~m}$ & $1.50 \mathrm{~m}$ \\
\hline & $1.47 \mathrm{ddd}(14.6,11.5,4.9)$ & $1.45 \mathrm{~m}$ & $1.45 \mathrm{~m}$ & $1.43 \mathrm{~m}$ & $1.43 \mathrm{~m}$ \\
\hline 9 & $1.81 \mathrm{~m}$ & $1.76 \mathrm{~m}$ & $1.75 \mathrm{~m}$ & $1.76 \mathrm{~m}$ & $1.75 \mathrm{~m}$ \\
\hline 10 & $2.02 \mathrm{~m}$ & $2.02 \mathrm{~m}$ & $2.02 \mathrm{~m}$ & $2.02 \mathrm{~m}$ & $2.02 \mathrm{~m}$ \\
\hline \multirow[t]{2}{*}{12} & $2.72 \mathrm{dt}(13.3,5.3)$ & $2.67 \mathrm{~m}$ & $2.66 \mathrm{~m}$ & $2.66 \mathrm{~m}$ & $2.65 \mathrm{~m}$ \\
\hline & $2.17 \mathrm{ddd}(13.7,9.9,4.4)$ & $2.21 \mathrm{~m}$ & $2.20 \mathrm{~m}$ & $2.21 \mathrm{~m}$ & $2.21 \mathrm{~m}$ \\
\hline \multirow[t]{2}{*}{13} & $2.22 \mathrm{ddt}(13.4,6.1,4.3)$ & $2.23 \mathrm{~m}$ & $2.22 \mathrm{~m}$ & $2.23 \mathrm{~m}$ & $2.23 \mathrm{~m}$ \\
\hline & $1.96 \mathrm{dtd}(13.7,9.7,4.5)$ & $1.98 \mathrm{~m}$ & $1.97 \mathrm{~m}$ & $1.99 \mathrm{~m}$ & $1.98 \mathrm{~m}$ \\
\hline 14 & $4.25 \mathrm{dd}(9.3,4.2)$ & $4.26 \mathrm{dd}(8.6,4.2)$ & $4.27 \mathrm{dd}(8.7,4.0)$ & $4.27 \mathrm{dd}(8.5,4.0)$ & $4.27 \mathrm{dd}(8.5,4.0)$ \\
\hline 16 & 5.90 br s & $5.77 \mathrm{br} \mathrm{s}$ & $5.75 \mathrm{br} \mathrm{s}$ & $5.78 \mathrm{br} \mathrm{s}$ & $5.75 \mathrm{br} \mathrm{s}$ \\
\hline 17 & $0.97_{5} \mathrm{~s}$ & $1.00 \mathrm{~s}$ & $0.99_{1} \mathrm{~s}$ & $1.00_{0} \mathrm{~s}$ & $0.99_{6} \mathrm{~s}$ \\
\hline 18 & $6.00 \mathrm{~s}$ & $5.92 \mathrm{~s}$ & $5.89 \mathrm{~s}$ & $5.92 \mathrm{~s}$ & $5.90 \mathrm{~s}$ \\
\hline 19 & $1.19 \mathrm{~s}$ & $1.17 \mathrm{~s}$ & $1.17 \mathrm{~s}$ & $1.16 \mathrm{~s}$ & $1.16 \mathrm{~s}$ \\
\hline 20 & $0.97_{1} \mathrm{~s}$ & $0.99 \mathrm{~s}$ & $0.989 \mathrm{~s}$ & $1.00_{4} \mathrm{~s}$ & $1.00_{2} \mathrm{~s}$ \\
\hline $2^{\prime}$ & $7.74 \mathrm{~d}(2.1)$ & $7.16 \mathrm{~d}(2.4)$ & $7.17 \mathrm{~d}(2.3)$ & $7.31 \mathrm{~d}(2.1)$ & $7.31 \mathrm{~d}(2.1)$ \\
\hline $5^{\prime}$ & $6.82 \mathrm{~d}(8.3)$ & - & - & - & - \\
\hline $6^{\prime}$ & $7.71 \mathrm{dd}(8.5,2.1)$ & $7.46 \mathrm{~d}(2.4)$ & $7.66 \mathrm{~d}(2.3)$ & $7.61 \mathrm{~d}(2.1)$ & $7.82 \mathrm{~d}(2.1)$ \\
\hline
\end{tabular}


Table 2. ${ }^{13} \mathrm{C}$ NMR Spectroscopic Data (200 MHz) of Iodocallophycoic Acid A (1) and Iodocallophycols $\mathrm{A}-\mathrm{D}(\mathbf{2}-\mathbf{5})$ in $\mathrm{CD}_{3} \mathrm{OD}$.

\begin{tabular}{lrrrrr}
\hline \multirow{2}{*}{ position } & \multicolumn{5}{c}{$\delta_{\text {C }}($ mult $)$} \\
\cline { 2 - 6 } & $\mathbf{1}$ & $\mathbf{2}$ & $\mathbf{3}$ & $\mathbf{4}$ & $\mathbf{5}$ \\
\hline 1 & $27.7(\mathrm{t})$ & $28.6(\mathrm{t})$ & $28.9(\mathrm{t})$ & $28.4(\mathrm{t})$ & $28.8(\mathrm{t})$ \\
2 & $51.0(\mathrm{~d})$ & $51.4(\mathrm{~d})$ & $51.2(\mathrm{~d})$ & $51.6(\mathrm{~d})$ & $51.5(\mathrm{~d})$ \\
3 & $148.2(\mathrm{~s})$ & $148.2(\mathrm{~s})$ & $148.1(\mathrm{~s})$ & $148.1(\mathrm{~s})$ & $148.1(\mathrm{~s})$ \\
4 & $37.7(\mathrm{t})$ & $36.6(\mathrm{t})$ & $36.9(\mathrm{t})$ & $36.6(\mathrm{t})$ & $36.8(\mathrm{t})$ \\
5 & $34.9(\mathrm{t})$ & $34.6(\mathrm{t})$ & $34.7(\mathrm{t})$ & $34.6(\mathrm{t})$ & $34.6(\mathrm{t})$ \\
6 & $63.1(\mathrm{~d})$ & $62.8(\mathrm{~d})$ & $62.8(\mathrm{~d})$ & $62.8(\mathrm{~d})$ & $62.8(\mathrm{~d})$ \\
7 & $45.5(\mathrm{~s})$ & $45.3(\mathrm{~s})$ & $45.3(\mathrm{~s})$ & $45.2(\mathrm{~s})$ & $45.2(\mathrm{~s})$ \\
8 & $39.4(\mathrm{t})$ & $39.5(\mathrm{t})$ & $39.4(\mathrm{t})$ & $39.5(\mathrm{t})$ & $39.5(\mathrm{t})$ \\
9 & $20.8(\mathrm{t})$ & $21.2(\mathrm{t})$ & $21.1(\mathrm{t})$ & $21.2(\mathrm{t})$ & $21.4(\mathrm{t})$ \\
10 & $57.5(\mathrm{~d})$ & $57.4(\mathrm{~d})$ & $57.3(\mathrm{~d})$ & $57.4(\mathrm{~d})$ & $57.4(\mathrm{~d})$ \\
11 & $149.6(\mathrm{~s})$ & $149.7(\mathrm{~s})$ & $149.7(\mathrm{~s})$ & $149.8(\mathrm{~s})$ & $149.8(\mathrm{~s})$ \\
12 & $36.5(\mathrm{t})$ & $35.8(\mathrm{t})$ & $35.8(\mathrm{t})$ & $35.6(\mathrm{t})$ & $35.5(\mathrm{t})$ \\
13 & $35.2(\mathrm{t})$ & $35.1(\mathrm{t})$ & $35.1(\mathrm{t})$ & $35.1(\mathrm{t})$ & $35.1(\mathrm{t})$ \\
14 & $65.9(\mathrm{~d})$ & $65.9(\mathrm{~d})$ & $65.9(\mathrm{~d})$ & $65.9(\mathrm{~d})$ & $65.9(\mathrm{~d})$ \\
15 & $43.2(\mathrm{~s})$ & $43.0(\mathrm{~s})$ & $43.0(\mathrm{~s})$ & $42.9(\mathrm{~s})$ & $42.9(\mathrm{~s})$ \\
16 & $75.8(\mathrm{~d})$ & $75.7(\mathrm{~d})$ & $75.9(\mathrm{~d})$ & $75.8(\mathrm{~d})$ & $75.9(\mathrm{~d})$ \\
17 & $18.8(\mathrm{q})$ & $19.3(\mathrm{q})$ & $19.2(\mathrm{q})$ & $19.4(\mathrm{q})$ & $19.3(\mathrm{q})$ \\
18 & $74.5(\mathrm{~d})$ & $74.4(\mathrm{~d})$ & $74.5(\mathrm{~d})$ & $74.5(\mathrm{~d})$ & $74.5(\mathrm{~d})$ \\
19 & $28.9(\mathrm{q})$ & $28.9(\mathrm{q})$ & $28.9(\mathrm{q})$ & $29.0(\mathrm{q})$ & $29.0(\mathrm{q})$ \\
20 & $20.4(\mathrm{q})$ & $21.1(\mathrm{q})$ & $21.1(\mathrm{q})$ & $21.3(\mathrm{q})$ & $21.2(\mathrm{q})$ \\
$1^{\prime}$ & $123.0(\mathrm{~s})$ & $112.9(\mathrm{~s})$ & $113.9(\mathrm{~s})$ & $82.2(\mathrm{~s})$ & $83.6(\mathrm{~s})$ \\
$2^{\prime}$ & $132.8(\mathrm{~d})$ & $132.5(\mathrm{~d})$ & $133.1(\mathrm{~d})$ & $138.6(\mathrm{~d})$ & $139.2(\mathrm{~d})$ \\
$3^{\prime}$ & $127.8(\mathrm{~s})$ & $132.9(\mathrm{~s})$ & $132.1(\mathrm{~s})$ & $133.4(\mathrm{~s})$ & $132.7(\mathrm{~s})$ \\
$4^{\prime}$ & $160.9(\mathrm{~s})$ & $152.3(\mathrm{~s})$ & $154.9(\mathrm{~s})$ & $152.9(\mathrm{~s})$ & $155.5(\mathrm{~s})$ \\
$5^{\prime}$ & $115.6(\mathrm{~d})$ & $112.6(\mathrm{~s})$ & $88.2(\mathrm{~s})$ & $112.9(\mathrm{~s})$ & $88.8(\mathrm{~s})$ \\
$6^{\prime}$ & $130.6(\mathrm{~d})$ & $133.5(\mathrm{~d})$ & $139.5(\mathrm{~d})$ & $139.3(\mathrm{~d})$ & $145.3(\mathrm{~d})$ \\
$7^{\prime}$ & $170.5(\mathrm{~s})$ & - & - & - & - \\
\hline
\end{tabular}



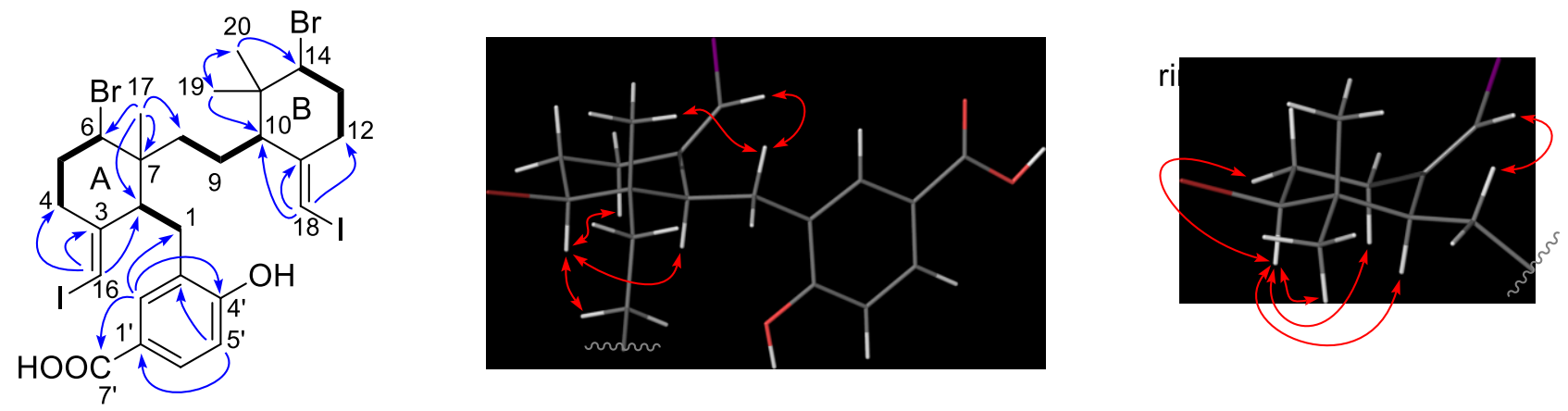

Figure 1. Key ${ }^{1} \mathrm{H}-{ }^{1} \mathrm{H} \operatorname{COSY}(-),{ }^{1} \mathrm{H}-{ }^{13} \mathrm{C} \mathrm{HMBC}(\rightarrow)$, and ${ }^{1} \mathrm{H}-{ }^{1} \mathrm{H}$ NOESY $(\leftrightarrow)$ correlations of iodocallophycoic acid A (1).

To determine the relative stereochemistry of iodocallophycoic acid A (1), the axial orientations of H-6 and H-14 were first established by the large coupling constants with their respective vicinal partners $\left({ }^{3} J_{\mathrm{H} 6 \mathrm{ax}, \mathrm{H} 5 \mathrm{ax}}=10.5 \mathrm{~Hz},{ }^{3} J_{\mathrm{H} 14 \mathrm{ax}, \mathrm{H} 13 \mathrm{ax}}=9.3 \mathrm{~Hz}\right)$. For ring A, NOESY correlations were observed from H-6 to $\mathrm{H}-4_{\mathrm{ax}}, \mathrm{H}-5_{\mathrm{eq}}$, and $\mathrm{H}_{2}-9$. The latter implied that the ethylene bridge to ring B was $\alpha$-oriented and the $\mathrm{H}_{3}-17$ was $\beta$-oriented (Figure 1). Another NOESY correlation could be seen between H-6 and H-2 allowing the assignment of the benzylic moiety in the $\beta$ position. The relative stereochemistry within ring $\mathrm{B}$ was determined from NOESY correlations between $\mathrm{H}-14, \mathrm{H}-10$ and $\mathrm{H}_{3}-19$, indicating that the bromine atom, the ethylene bridge, and the methyl at position 20 resided on the same side of the ring. These observations ruled out most of the possible stereoisomers leaving only $2 S^{*}, 6 S^{*}, 7 S^{*}, 10 S^{*}, 14 S^{*}$, $2 S^{*}, 6 S^{*}, 7 S^{*}, 10 R^{*}, 14 R^{*}$, and their enantiomeric counterparts. Although a NOESY correlation between H$2^{\prime}$ and H-18 was observed, the flexible nature of the ethylene bridge prevented an unambiguous conclusion about the relative stereochemistry between the two rings.

Similarly challenging structural elucidation has been previously accomplished: the relative configuration of the macrocyclic diterpene jatrohemiketal (9) was elucidated by predicting ${ }^{1} \mathrm{H}$ and ${ }^{13} \mathrm{C}$ NMR chemical shifts through DFT calculation. ${ }^{22}$ It was further validated by comparison of dihedral angles and interproton distances obtained by molecular modeling with the corresponding values derived by vicinal ${ }^{1} \mathrm{H}-$ ${ }^{1} \mathrm{H}$ coupling constants and ROESY. In another example, the absolute stereochemistry of abibalsamin $\mathrm{C}$ 
(10) was determined by semi-quantitative ROESY distance calculation and DFT modeling. ${ }^{23}$ Using quantitative NOESY and MTPA derivatives, the absolute configuration of plakilactone H (11), isolated from the marine sponge Plakinastrella mamillaris, was determined. ${ }^{24}$ Based on these previous approaches, the only two remaining diastereoisomers $\left(2 S^{*}, 6 S^{*}, 7 S^{*}, 10 S^{*}, 14 S^{*}\right.$ or $\left.2 S^{*}, 6 S^{*}, 7 S^{*}, 10 R^{*}, 14 R^{*}\right)$ of iodocallophycoic acid A (1) were modeled in order to compare the distances with those calculated from the quantitative NOESY spectrum.

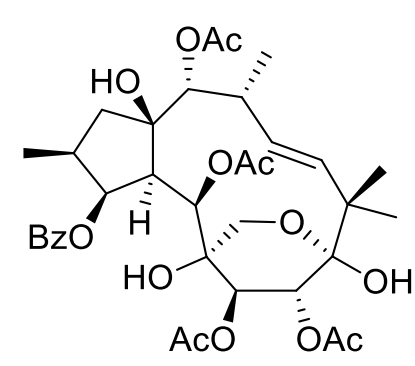

9

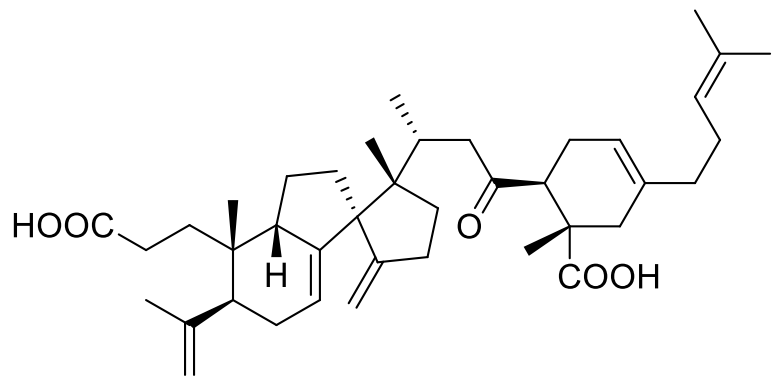

10

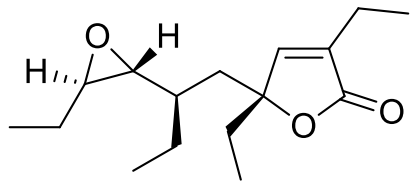

11

The arbitrarily configured $2 S, 6 S, 7 S$ stereoisomers of iodocallophycoic acid A (1), either $10 S, 14 S$ or $10 R, 14 R$, were subjected to a conformational search using Spartan yielding 14 and 15 different conformers within a $21 \mathrm{~kJ} \mathrm{~mol}^{-1}$ window, respectively. Their geometries were optimized at the B3LYP/SVP level of theory using Gaussian (Table S1-S4). ${ }^{25}$ The thermochemical parameters were then calculated at the same level of theory in order to determine the Boltzmann distribution at $298 \mathrm{~K}$ (Table S5) and the most stable conformers of each hypothetical diastereoisomer (Figure 2). The relevant inter-atomic distances for the most stable conformers $\left(<5 \mathrm{~kJ} \mathrm{~mol}^{-1}\right)$ were then extracted and weighted, according to their calculated relative abundances. Concurrently, slices from the 2D NOESY spectrum were extracted in the F2 direction and both the diagonal and the cross-peaks were integrated. ${ }^{26}$ The normalized values were transformed into distances using the distance between $\mathrm{H}-5^{\prime}$ and $\mathrm{H}-\mathrm{6}^{\prime}$ as a reference (Table 3). The mean absolute error (MAE), calculated between the NOESY and the DFT distances, was lower when the model $2 S, 6 S, 7 S, 10 S, 14 S$ was considered $(0.23 \AA$ for $2 S, 6 S, 7 S, 10 S, 14 S$ vs. $0.34 \AA$ for $2 S, 6 S, 7 S, 10 R, 14 R)$. 
Moreover, the distance between H-18 and H-2' was of particular significance since it connected both ring moieties. In that case, the NOESY derived distance (3.81 $\AA$ ) was found to be much closer to the DFTdistance for the $2 S, 6 S, 7 S, 10 S, 14 S$ model (3.64 $\AA$ ) than for the $2 S, 6 S, 7 S, 10 R, 14 R$ model $(6.17 \AA)$.
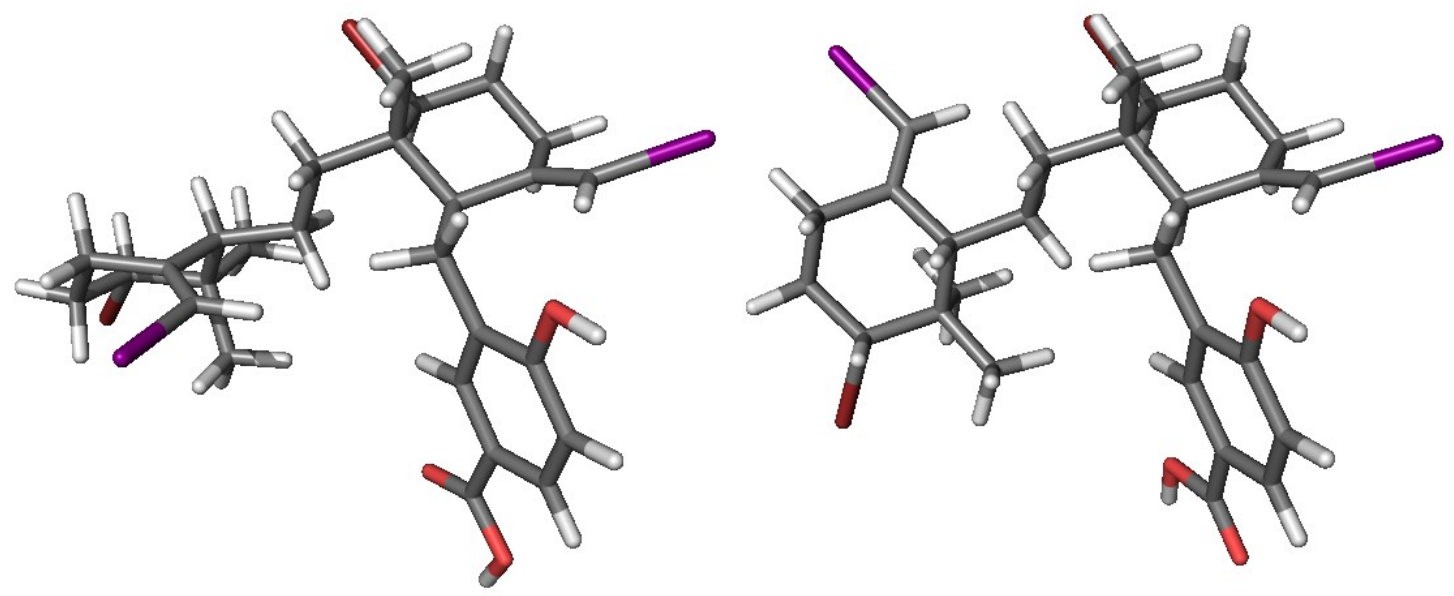

Figure 2. Most stable DFT calculated conformers of the hypothetical diastereoisomers $2 S, 6 S, 7 S, 10 S, 14 S$ (left) and $2 S, 6 S, 7 S, 10 R, 14 R$ (right) for iodocallophycoic acid A (1). 
Table 3. Comparison of Inter-Proton Distances Determined by 2D NOESY and DFT Calculation for Iodocallophycoic acid A (1).

\begin{tabular}{|c|c|c|c|c|}
\hline \multirow{3}{*}{\multicolumn{2}{|c|}{ Protons }} & \multicolumn{3}{|c|}{ Distances $(\AA)$} \\
\hline & & & \multicolumn{2}{|c|}{ DFT-calculated $^{\mathrm{b}}$} \\
\hline & & & $2 S, 6 S, 7 S, 10 S, 14 S-\mathbf{1}$ & $2 \mathrm{~S}, 6 S, 7 S, 10 R, 14 R \mathbf{- 1}$ \\
\hline $1 \mathrm{ax}$ & 6 & 3.74 & 4.83 & 2.41 \\
\hline $1 \mathrm{ax}$ & 16 & 2.30 & 2.15 & 2.22 \\
\hline $1 \mathrm{ax}$ & $2^{\prime}$ & 3.01 & 2.94 & 2.81 \\
\hline $1 \mathrm{eq}$ & 18 & 2.89 & 2.36 & 4.41 \\
\hline 2 & 6 & 2.53 & 2.44 & 2.41 \\
\hline 2 & 16 & 2.82 & 3.59 & 3.60 \\
\hline 2 & $2^{\prime}$ & 2.43 & 2.37 & 2.40 \\
\hline $4 a x$ & 6 & 2.78 & 2.61 & 2.64 \\
\hline $5 \mathrm{ax}$ & 6 & 2.97 & 3.06 & 3.06 \\
\hline $5 \mathrm{eq}$ & 6 & 2.48 & 2.44 & 2.44 \\
\hline 6 & $8 a$ & 3.24 & 3.68 & 3.66 \\
\hline 6 & $8 b$ & 3.16 & 3.01 & 3.11 \\
\hline 6 & 9 & 2.17 & 2.75 & 2.72 \\
\hline $8 \mathrm{a}$ & 18 & 2.80 & 2.43 & 2.36 \\
\hline $8 b$ & 18 & 3.80 & 3.75 & 3.75 \\
\hline 9 & 18 & 2.29 & 2.63 & 2.62 \\
\hline 10 & 14 & 2.66 & 2.41 & 2.42 \\
\hline 10 & 18 & 2.82 & 3.62 & 3.61 \\
\hline $12 \mathrm{ax}$ & 14 & 2.92 & 2.67 & 2.65 \\
\hline $13 a x$ & 14 & 2.99 & 3.07 & 3.07 \\
\hline $13 \mathrm{eq}$ & 14 & 2.55 & 2.45 & 2.45 \\
\hline 16 & $2^{\prime}$ & 2.90 & 2.88 & 2.96 \\
\hline 18 & 20 & 3.99 & 3.73 & 3.79 \\
\hline 18 & $2^{\prime}$ & 3.81 & 3.64 & 6.17 \\
\hline $5^{\prime}$ & $6^{\prime}$ & $2.49^{c}$ & 2.49 & 2.50 \\
\hline $\mathrm{MAE}^{\mathrm{d}}$ & & & 0.24 & 0.34 \\
\hline
\end{tabular}

${ }^{a} \overline{\text { Distances calculated from the NOESY spectrum of 1; }{ }^{b} \text { Distances averaged from the }}$ most stable conformers of the DFT models; ${ }^{\mathrm{c}}$ Reference used for calculation of NOESY distances; ${ }^{\mathrm{d}}$ Mean absolute error.

The absolute stereochemistry of $\mathbf{1}$ was determined by ECD spectroscopy and TDDFT calculation. The theoretical models previously developed were refined by geometrical optimization of the conformers in acetonitrile (Table S6-S9), followed by calculation of the thermochemical parameters (Table S10). For further validation of the previous conclusion, both diastereoisomers $2 S, 6 S, 7 S, 10 S, 14 S$ and $2 S, 6 S, 7 S, 10 R, 14 R$ were considered at this step. The predicted ECD spectra, computed using TDDFT at the B3LYP/svp level of theory, were normalized and compared to the experimental spectrum (Figure 3). 
The shape of the calculated spectrum for the $2 S, 6 S, 7 S, 10 S, 14 S$ diastereoisomers better fit the experimental spectrum. Hence, with all the above evidence, 1 was assigned as $2 S, 6 S, 7 S, 10 S, 14 S$-iodocallophycoic acid A.

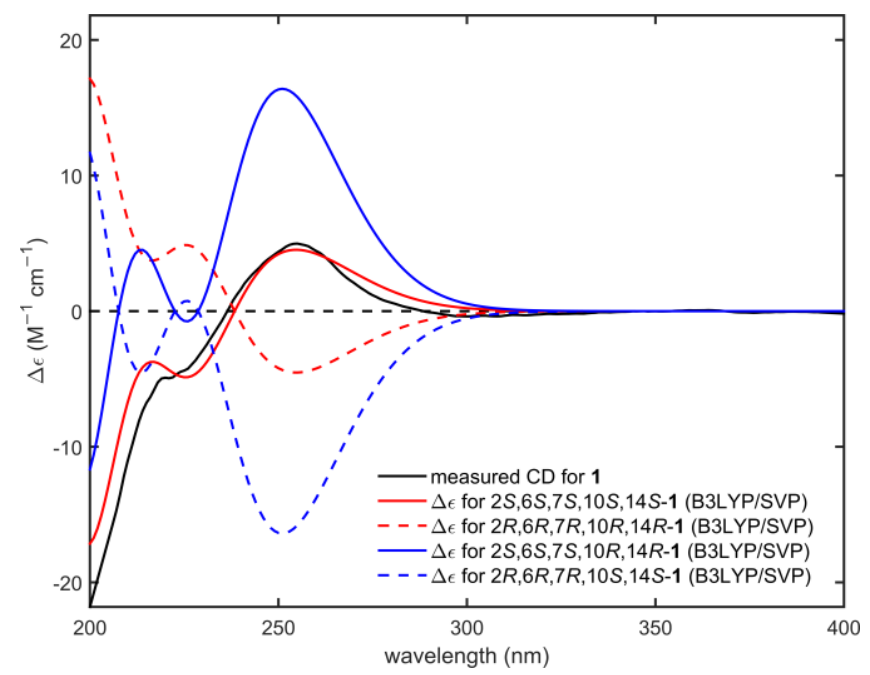

Figure 3. Experimental and TDDFT calculated ECD spectra of iodocallophycoic acid A (1) in acetonitrile.

The discovery of an iodinated natural product prompted us to search for related analogs. Low-resolution mass spectrometric data for extracts of Callophycus sp. suggested that other compounds with masses above 700 Da might be present. Compound 2 was obtained as a white amorphous solid with a molecular formula of $\mathrm{C}_{26} \mathrm{H}_{32} \mathrm{Br}_{4} \mathrm{I}_{2} \mathrm{O}$, as determined by HRESIMS ( $m / z$ 928.7211, calcd for $\mathrm{C}_{26} \mathrm{H}_{31} \mathrm{Br}_{4} \mathrm{I}_{2} \mathrm{O}[\mathrm{M}-\mathrm{H}]^{-}$ 928.7203). The ${ }^{1} \mathrm{H}$ and ${ }^{13} \mathrm{C}$ NMR spectroscopic data (Tables 1 and 2) shared strong similarity with iodocallophycoic acid A (1). Close examination of the 2D spectroscopic data revealed that the system of two cyclohexane rings was identical. However, the simplified aromatic region of the ${ }^{1} \mathrm{H}$ NMR spectrum, displaying two weakly coupled (meta) doublets at $\delta_{\mathrm{H}} 7.46$ and $7.16(\mathrm{~d}, J=2.4 \mathrm{~Hz})$ and the absence of carboxylic carbon signal in the ${ }^{13} \mathrm{C}$ and $\mathrm{HMBC}$ spectra suggested that the aromatic ring bore the difference between the two molecules. Two additional bromine atoms, evidenced by a 1:4:6:4:1 quintuplet mass cluster centered at $m / z$ 932.7, were assigned on the aromatic ring, based on quaternary carbon signals at 
$\delta_{\mathrm{C}} 112.9$ and $112.6 .{ }^{27}$ The HMBC correlations from H-1 to C-2', C-3', and C-4' allowed assignment of the phenol at $\mathrm{C}-4^{\prime}$ and an aromatic proton at $\mathrm{H}-2^{\prime}$. The precise assignment of brominated $\mathrm{C}-1^{\prime}$ and $\mathrm{C}-5^{\prime}$ was complex due to the proximity of their chemical shifts $\left(\Delta \delta_{\mathrm{C}} 0.3\right)$. To address this difficulty, the resolution of the HMBC spectrum was improved using forward linear prediction and ${ }^{13} \mathrm{C}$ traces were extracted for H-2' and H-6' (Figure 4). While H-6' correlated with both carbons, H-2' only correlated with $\delta$ c 112.9 , which was therefore assigned to $\mathrm{C}-1^{\prime}$, completing the assignment of atomic connectivity for iodocallophycol A (2).

Compounds 3-5 were all obtained as white amorphous solids. Their HRESIMS spectra showed masses at $\mathrm{m} / \mathrm{z}$ 976.7063, 976.7062, and 1024.6926, respectively, consistent with a molecular formula of $\mathrm{C}_{26} \mathrm{H}_{32} \mathrm{Br}_{3} \mathrm{I}_{3} \mathrm{O}$ for 3 and $\mathbf{4}$, and $\mathrm{C}_{26} \mathrm{H}_{32} \mathrm{Br}_{2} \mathrm{I}_{4} \mathrm{O}$ for 5. Like 2, the iodinated terpene portion of 3-5 was identical to iodocallophycoic acid A (1), as demonstrated by the ${ }^{1} \mathrm{H}$ and ${ }^{13} \mathrm{C}$ NMR spectroscopic data (Tables 1-2). Again, the absence of carboxylic carbon signal in the ${ }^{13} \mathrm{C}$ NMR spectrum and the metacoupled aromatic ${ }^{1} \mathrm{H}$ doublets, albeit at different $\delta_{\mathrm{H}}$ than for $\mathbf{2}$, suggested that the aromatic rings bore halogen substituents. Distinct ranges of chemical shift ranges were observed for halogenated carbons of 3-5: either $\delta$ C $112-114$ or $82-89$, which correspond to brominated or iodinated aromatic carbons, respectively. ${ }^{15}$ The same strategy used to characterize the aromatic ring of 2 was followed; namely, determination of $\mathrm{C}-2^{\prime}$ and $\mathrm{C}-4^{\prime}$ from $\mathrm{HMBC}$ correlation with $\mathrm{H}_{2}-1$ and determination of the halogens substitution pattern on $\mathrm{C}-1^{\prime}$ and $\mathrm{C}-5^{\prime}$ with the help of HMBC correlations from $\mathrm{H}-2^{\prime}$. The observation of a ${ }^{4} J$ HMBC correlation between $\mathrm{H}-2^{\prime}$ and $\mathrm{C}-5^{\prime}$ seemed initially problematic, but this correlation was considerably weaker than ${ }^{2} J_{\mathrm{H}-2^{\prime}, \mathrm{C}-1^{\prime}}($ Figure 4). In summary, compounds 2-5 had 1',5'-dibromo-4'-hydroxy(2), 1'-bromo-4'-hydroxy-5'-iodo- (3), 5'-bromo-4'-hydroxy-1'-iodo- (4), and 4'-hydroxy-1',5'-diiodosubstituted (5) phenyl rings, and were named iodocallophycol A-D. Natural products with three or four iodines are unprecedented in red algae. 
The relative stereochemistries of 2-5 were determined using NOESY. The same correlations observed for iodocallophycoic acid A (1) were present for 2-5, including the long distance correlation between H-2' and $\mathrm{H}-18$. The specific optical rotations for each of these compounds were levorotatory, as for 1, providing strong evidence for the absolute stereochemistries of iodocallophycols A-D (2-5) as depicted.

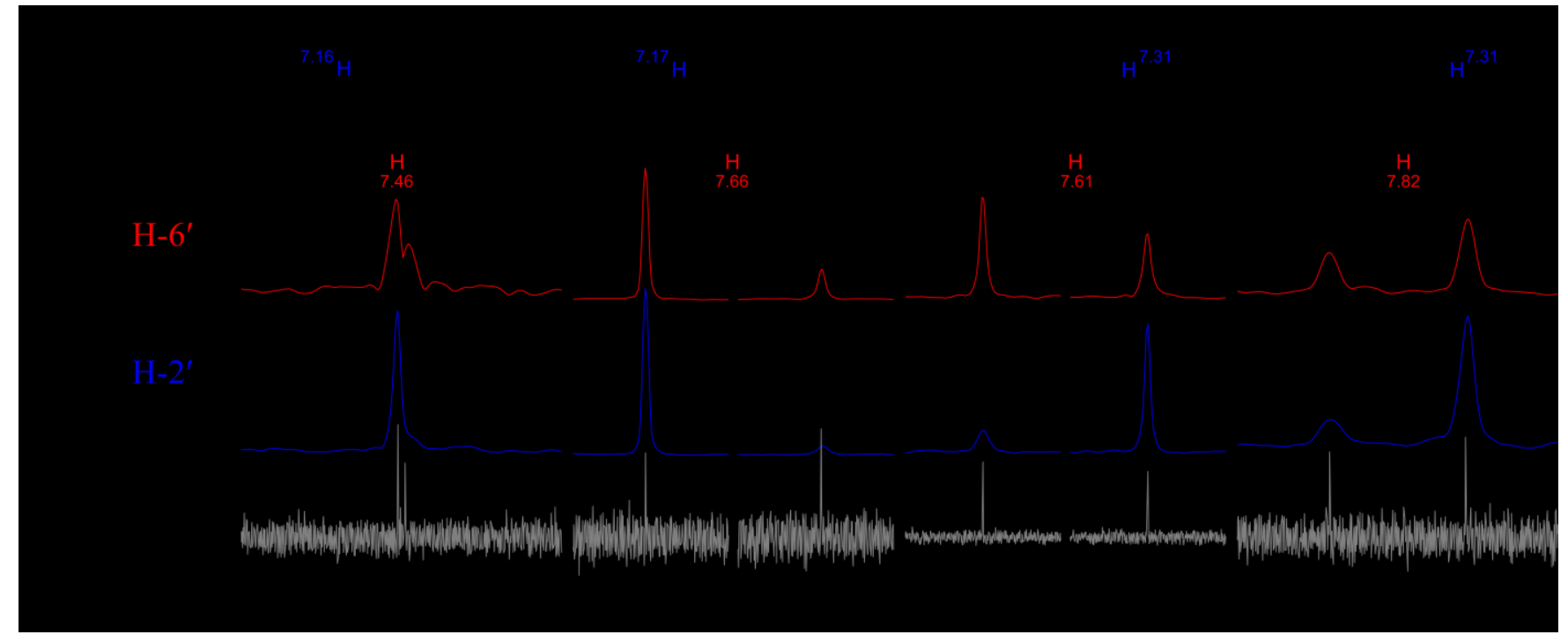

Figure 4. $\mathrm{HMBC}{ }^{13} \mathrm{C}$ projections for $\mathrm{H}-2^{\prime}$ and $\mathrm{H}-6{ }^{\prime}$, overlaid on the ${ }^{13} \mathrm{C}$ spectrum of the respective iodocallophycols A-D (2-5).

During the fractionation process, two additional compounds were incidentally isolated. Compound $\mathbf{6}$ was isolated as a white amorphous solid. Two negatively charged molecular ions with $\mathrm{m} / \mathrm{z} 485.1686$ and 487.1665 were observed by HRESIMS suggesting a molecular formula of $\mathrm{C}_{27} \mathrm{H}_{35} \mathrm{BrO}_{3}$. Examination of the NMR spectroscopic data (Table 4) showed that 6 possessed a 1,2,4-trisubstituted aromatic ring as well as 4-methylpent-3-enyl and bromomethine moieties, similar to bromophycoic acids A-E (12-16) previously described from the same alga. ${ }^{19}$ The spin group composed of $\mathrm{H}-2$ and $\mathrm{H}_{2}-1$ correlates with C3', C-3 and C-4', as shown by the HMBC spectrum, suggesting that a double bond was present on the decalin ring system where the coumaran moiety was attached. The double bond was ascertained at C-3 because of COSY correlations between $\mathrm{H}-4$ and $\mathrm{H}_{2}-5$. The remainder of the structure was identical to bromophycoic acid A (12). The molecule was thus named bromophycoic acid F (6). 
Table 4. NMR Spectroscopic Data of Bromophycoic Acid F (6) and Bromophycoic Acid A Methyl Ester (7) in $\mathrm{CD}_{3} \mathrm{OD}$.

\begin{tabular}{|c|c|c|c|c|}
\hline \multirow{2}{*}{ position } & \multicolumn{2}{|r|}{6} & \multicolumn{2}{|r|}{7} \\
\hline & $\delta_{\mathrm{C}^{\mathrm{a}}}$ & $\delta_{\mathrm{C}}$ mult. $(J \text { in } \mathrm{Hz})^{\mathrm{b}}$ & $\delta \mathrm{C}^{\mathrm{a}}$ & $\delta_{\mathrm{C}}$ mult. $(J \text { in } \mathrm{Hz})^{\mathrm{b}}$ \\
\hline \multirow[t]{2}{*}{1} & $34.6(t)$ & 3.35 , dd $(15.7,9.8)$ & $30.5(\mathrm{t})$ & $3.32 \mathrm{dd}(16.2,8.7)$ \\
\hline & & $3.00, \mathrm{dd}(15.8,7.7)$ & & $3.15 \mathrm{dd}(15.4,9.5)$ \\
\hline 2 & $88.8(\mathrm{~d})$ & $5.24, \mathrm{t}(8.7)$ & 87.9 (d) & $5.22 \mathrm{t}(9.1)$ \\
\hline 3 & $136.0(\mathrm{~s})$ & & $73.4(\mathrm{~s})$ & \\
\hline 4 & $124.1(\mathrm{~d})$ & $5.78, \mathrm{dt}(5.2,2.6)$ & $37.7(t)$ & $2.53 \mathrm{dq}(13.0,3.0)$ \\
\hline \multirow[t]{2}{*}{5} & $25.6(\mathrm{t})$ & $2.15, \operatorname{dtd}(18.1,5.8,2.9)$ & $21.6(\mathrm{t})$ & $1.67 \mathrm{~m}$ \\
\hline & & $2.07, \mathrm{~m}$ & & $1.55 \mathrm{~m}$ \\
\hline 6 & $44.3(d)$ & $1.69, \mathrm{dd}(11.9,5.2)$ & $49.4(d)$ & $1.41 \mathrm{~m}$ \\
\hline 7 & $33.4(\mathrm{~s})$ & & $35.6(\mathrm{~s})$ & \\
\hline \multirow[t]{2}{*}{8} & $43.4(\mathrm{t})$ & $1.57, \mathrm{dt}(13.7,3.5)$ & $44.5(\mathrm{t})$ & $1.50 \mathrm{dt}(13.4,3.5)$ \\
\hline & & $1.35, \operatorname{td}(12.6,4.1)$ & & $1.32 \operatorname{td}(13.5,3.9)$ \\
\hline \multirow[t]{2}{*}{9} & $32.1(\mathrm{t})$ & 2.27, qd $(13.4,3.6)$ & $32.0(\mathrm{t})$ & $2.30 \mathrm{qd}(13.3,3.8)$ \\
\hline & & $2.07, \mathrm{~m}$ & & $2.10 \mathrm{dq}(13.6,3.8)$ \\
\hline 10 & $65.1(d)$ & $4.35, \mathrm{dd}(12.5,3.8)$ & $64.8(d)$ & $4.40 \mathrm{dd}(12.5,4.3)$ \\
\hline 11 & $42.6(\mathrm{~s})$ & & $42.7(\mathrm{~s})$ & \\
\hline \multirow[t]{2}{*}{12} & $40.3(\mathrm{t})$ & 1.48, ddd $(16.9,12.0,5.0)$ & $40.8(\mathrm{t})$ & $1.56 \mathrm{~m}$ \\
\hline & & $1.37, \operatorname{td}(14.0,5.0)$ & & $1.42 \mathrm{~m}$ \\
\hline \multirow[t]{2}{*}{13} & $22.2(\mathrm{t})$ & $1.95, \mathrm{tt}(12.5,6.0)$ & $22.3(\mathrm{t})$ & $1.98 \mathrm{tt}(12.6,5.9)$ \\
\hline & & $1.81, \mathrm{tt}(12.7,5.8)$ & & $1.86 \mathrm{tt}(12.7,6.0)$ \\
\hline 14 & $125.3(\mathrm{~d})$ & $5.09, \mathrm{t}(7.3)$ & $125.3(\mathrm{~d})$ & $5.13 \mathrm{t}(7.1)$ \\
\hline 15 & $132.5(\mathrm{~s})$ & & $132.5(\mathrm{~s})$ & \\
\hline 16 & $25.9(q)$ & 1.67, br s & $26.0(q)$ & 1.70 br s \\
\hline \multirow[t]{2}{*}{17} & $44.2(\mathrm{t})$ & 1.89, br d (16.9) & $55.0(\mathrm{t})$ & $1.64 \mathrm{dd}(13.9,2.4)$ \\
\hline & & $1.64, \mathrm{~m}$ & & $1.35 \mathrm{~d}(13.9)$ \\
\hline 18 & $20.2(q)$ & $0.96, \mathrm{~s}$ & $22.1(q)$ & $1.07 \mathrm{~s}$ \\
\hline 19 & $19.3(q)$ & $1.01, \mathrm{~s}$ & $19.9(q)$ & $0.93 \mathrm{~s}$ \\
\hline 20 & $17.8(\mathrm{q})$ & 1.63, br s & $17.8(q)$ & 1.66 br s \\
\hline $1^{\prime}$ & $124.1(\mathrm{~d})$ & & $123.3(\mathrm{~s})$ & \\
\hline $2^{\prime}$ & $127.9(\mathrm{~d})$ & $7.83, \mathrm{~m}$ & $127.5(\mathrm{~d})$ & $7.83 \mathrm{~d}(1.7)$ \\
\hline $3^{\prime}$ & $128.9(\mathrm{~s})$ & & $129.8(\mathrm{~s})$ & \\
\hline $4^{\prime}$ & $165.5(\mathrm{~s})$ & & $165.7(\mathrm{~s})$ & \\
\hline $5^{\prime}$ & $109.6(d)$ & $6.75, \mathrm{~d}(8.8)$ & 109.9 (d) & $6.79 \mathrm{~d}(8.4)$ \\
\hline $6^{\prime}$ & $132.4(d)$ & $7.83, \mathrm{~m}$ & $131.8(\mathrm{~d})$ & $7.81 \mathrm{dd}(8.4,1.9)$ \\
\hline $7^{\prime}$ & $170.00(\mathrm{~s})$ & & $168.6(\mathrm{~s})$ & \\
\hline $\mathrm{OCH}_{3}$ & - & - & $52.4(q)$ & $3.85 \mathrm{~s}$ \\
\hline
\end{tabular}


Compound 7 was isolated as a white amorphous powder and was shown to have the molecular formula $\mathrm{C}_{28} \mathrm{H}_{39} \mathrm{BrO}_{4}$ based on a molecular ion at $m / z 517.1951\left([\mathrm{M}-\mathrm{H}]^{-}\right)$by HRESIMS. The presence of a bromine atom was further confirmed by a second peak at $\mathrm{m} / \mathrm{z} 519.1928$ showing equal intensity. A close examination of the NMR spectroscopic data revealed a strong similarity of 7 with bromophycoic acid A (12) (Table 4). Only an additional methyl singlet at $\delta_{\mathrm{H}} 3.85$ could be observed and was assigned at C-1 based on an HMBC crosspeak. Because of this spectroscopic evidence, 7 was identified as the methyl ester of bromophycoic acid A. ${ }^{19}$

The relative configurations of bromophycoic acid F (6) and bromophycoic acid A methyl ester (7) are the same as for bromophycoic acid A (12), as suggested by similar correlations shown by NOESY spectra. The absolute stereochemistry was then determined by ECD spectroscopy and quantum-chemical computation. Following a similar approach to iodocallophycoic acid A (1), the ECD spectra were predicted and compared to the spectra recorded (Figure 5).The absolute stereochemistries of 6 and 7 , respectively $2 S, 6 R, 7 R, 10 S, 11 S$-bromophycoic acid $\mathrm{F}$ and $2 S, 3 R, 6 R, 7 R, 10 S, 11 S$-bromophycoic acid A methyl ester, are inverted relative to that originally depicted for bromophycoic acid A (12). ${ }^{19}$ The chirality of the latter and its analogs were not previously formally assigned. Since all these compounds are related biosynthetically, it is now reasonable to consider that bromophycoic acid F (6) and bromophycoic acid A methyl ester (7) share the same absolute stereochemistry as bromophycoic acids A-E (12-16), depicted correctly below. 

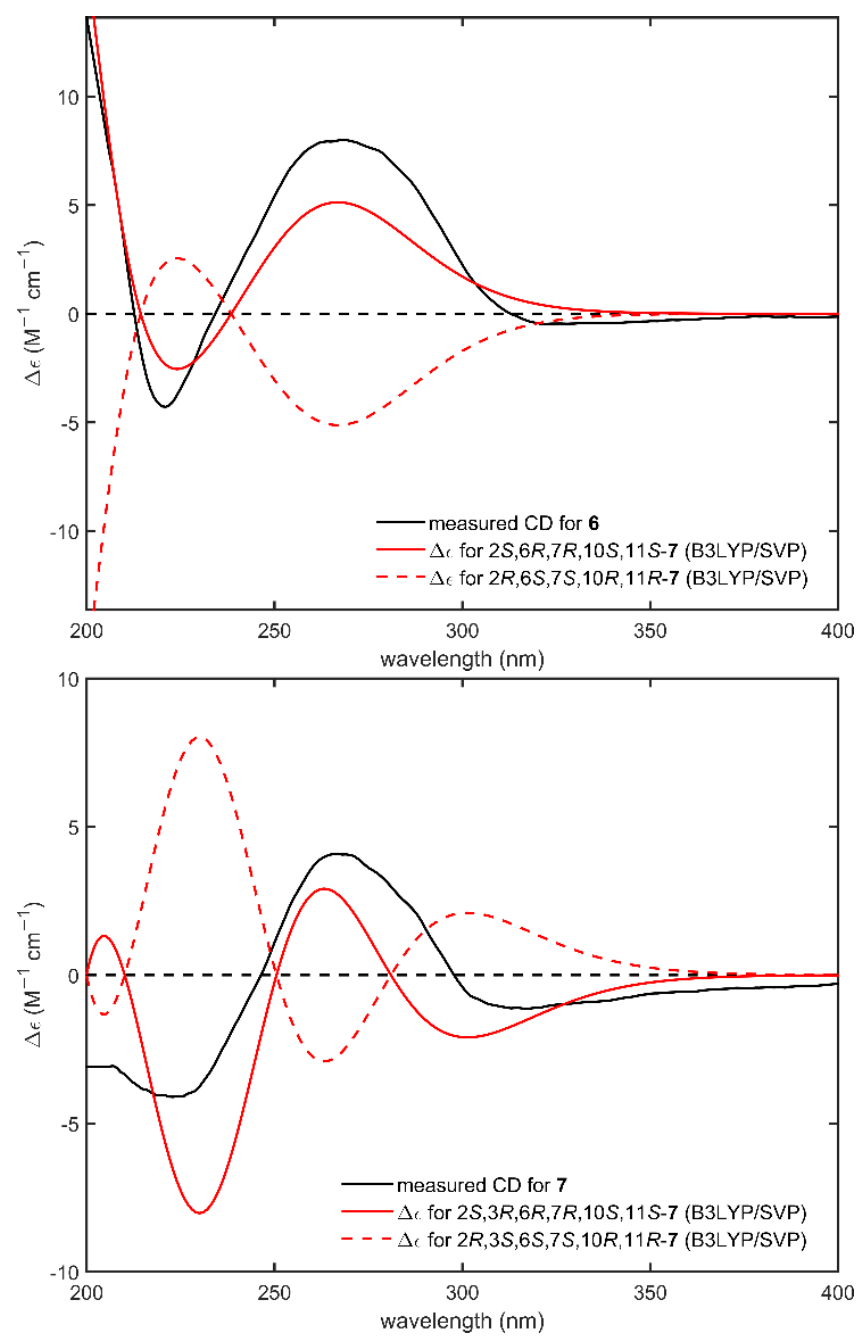

Figure 5. Experimental and TDDFT calculated ECD spectra of bromophycoic acids F (6) and bromophycoic acid A methyl ester (7) in acetonitrile. 

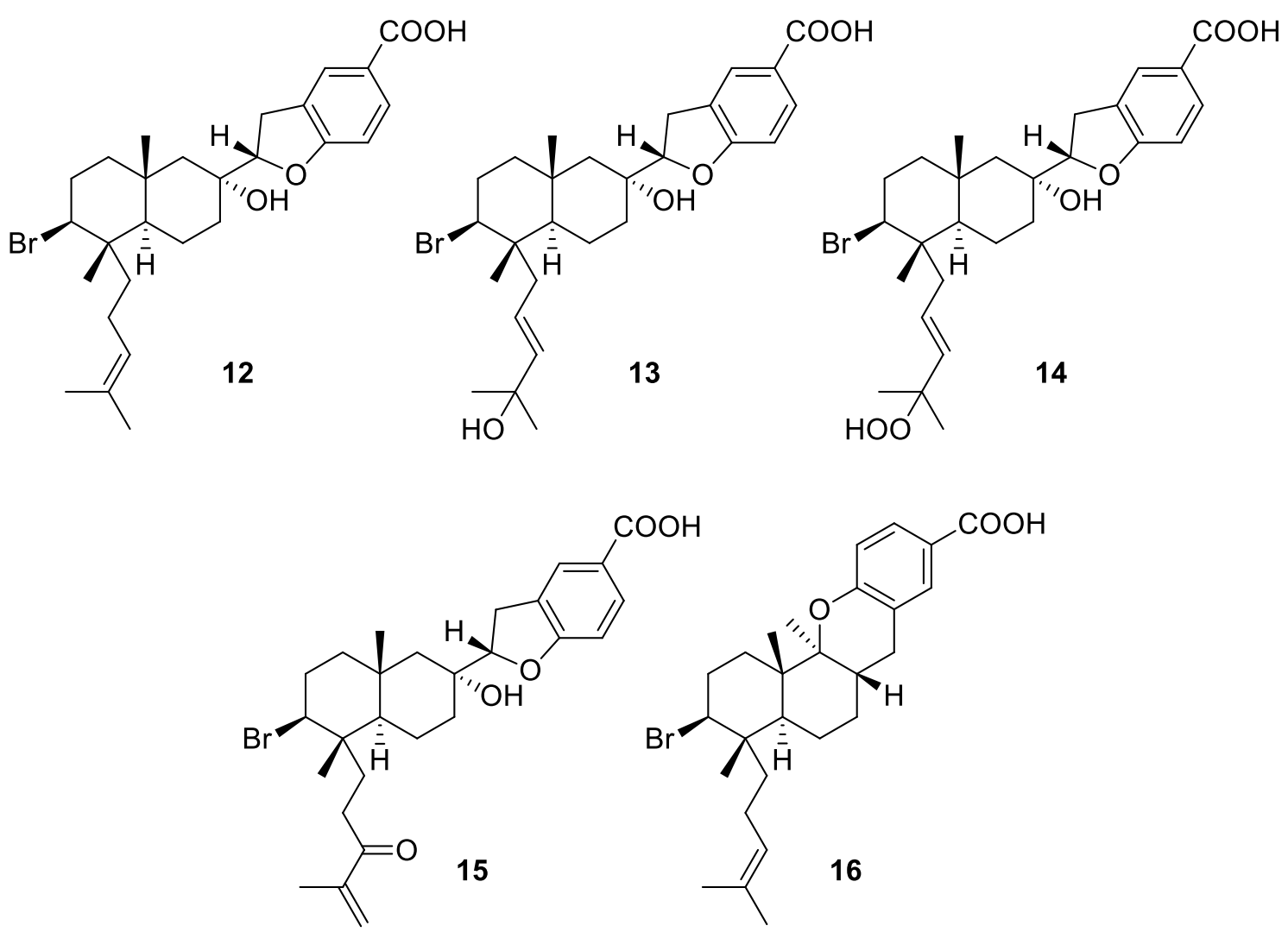

The isolation of an esterified natural product like bromophycoic acid A methyl ester (7) raised a question about its origin. Matsuda et al. demonstrated that epoxyfarnesyl-3,5-dimethylorsellinic acid was enzymatically methylated and that this process was essential for subsequent terpene cyclization. ${ }^{28}$ On the other hand, numerous examples of artifactual methylation have been reported previously. ${ }^{29-31}$ When smallscale extraction of Callophycus sp. was performed with either ethanol or methanol, followed by crude fractionation and analysis by LCMS. 7 was detected in both extracts (Figure 6). Furthermore, the ethyl ester derivative, expected in the case of a non-biogenic esterification, was not detected in the ethanol extract. Therefore, bromophycoic acid A methyl ester (7) should be considered a genuine natural product. 


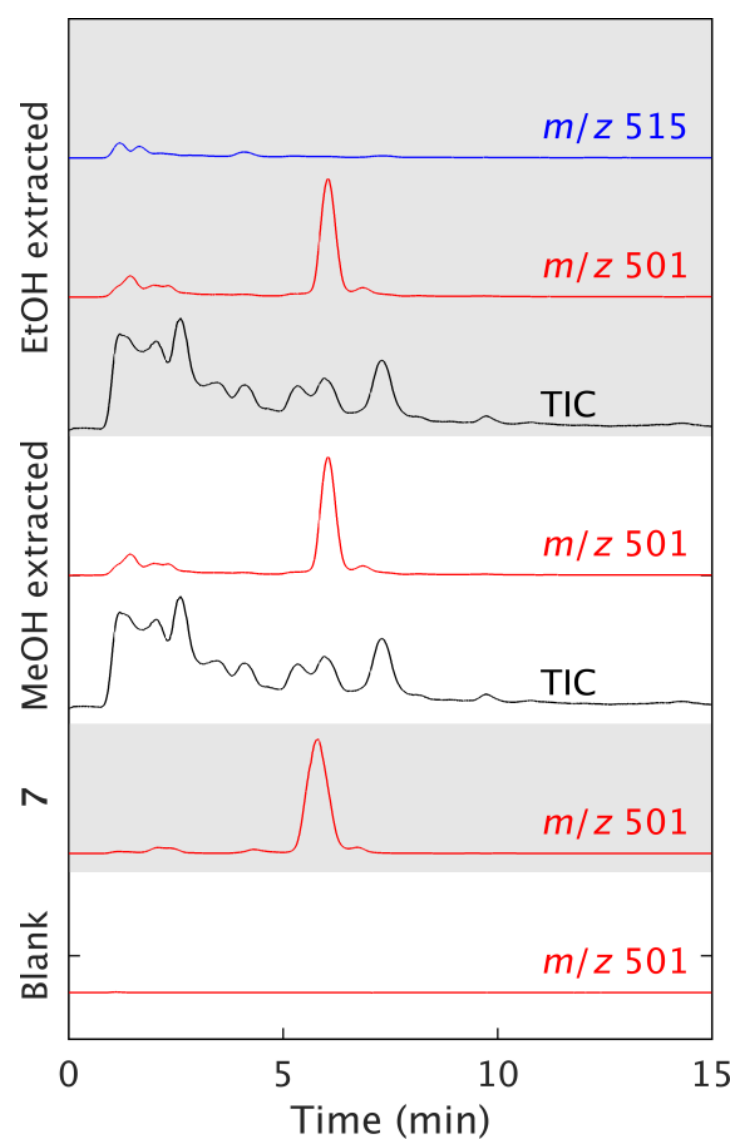

Figure 6. LCMS chromatogram of bromophycoic acid A methyl ester (7), and of two fractions originated from methanol or ethanol extracts of Callophycus sp. The $\left[\mathrm{M}+\mathrm{H}-\mathrm{H}_{2} \mathrm{O}\right]^{+}$ion of the methyl ester $(m / z 501)$ or the ethyl ester $(m / z 515)$ of bromophycoic acid A was monitored.

One additional natural product of Callophycus sp. isolated during these efforts attracted our attention: 3geranylgeranyl-4-hydroxybenzoic acid (8) identified by NMR spectroscopic data in comparison with the literature. ${ }^{32}$ The presence of this compound in Callophycus sp. has been proposed in the past to rationalize the biosynthesis of the many meroditerpenes isolated from members of this red algal genus since $2005,{ }^{33}$ but was not previously detected. ${ }^{27}$ This finding thus encouraged us to propose a biosynthetic pathway for iodocallophycoic acid A (1), iodocallophycols (2-5) and related bromophycoic acids. First, the two rings of $\mathbf{1}$ are expected to arise by cyclizations initiated by electrophilic bromination (Figure 7a). ${ }^{26}$ The resulting exocyclic double bonds are then expected to be iodinated at the terminal position, followed by loss of a proton to yield $\mathbf{1}$. The regioselectivity of bromine and iodine additions further supports their electrophilic 
character since all of them are found at the Markovnikov position. The formation of iodocallophycols AD (2-5) can be explained by halogenation at the activated phenol position (ortho) followed by decarboxylation of the hydroxybenzoic acid moiety, clearing the position for a second halogenation step (Figure 7b). The halogenation-decarboxylation-halogenation sequence of reactions is also likely in the formation of callophycoic acid $\mathrm{H}$ and callophycols $\mathrm{A}-\mathrm{B}$, previously isolated from another member of the Callophycus genus, likely Callophycus densus. ${ }^{27}$ For the bromophycoic acids, a coumaran ring system is first predicted to be obtained through the oxidation of an alkenic methyl group followed by the formation of the furan ring fused with the phenol group (Figure 7c). This step is required to obtain bromophycoic acids A-D (12-15), F (6), and bromophycoic acid A methyl ester (7), more specifically, with the 4hydroxybenzoic acid moiety bonded at position 2 of the decalin system rather than at position 1 as for callophycoic acids $\mathrm{G}$ and $\mathrm{H}$ (Figure $7 \mathrm{~d}$ ). ${ }^{27}$ The decalin rings can then be formed by a reaction cascade initiated by the bromination of one double bond (Figure 7e). The loss of a proton, preceded or not by the addition of water, allows the formation of bromophycoic acids A (12) and F (6). The methylation of the carboxylic acid group of bromophycoic acid A (12) leads to bromophycoic acid A methyl ester (7). Finally, bromophycoic acids B-D (13-15) can be obtained through a sequence of oxidation steps of the side chain (Figure 7f). 

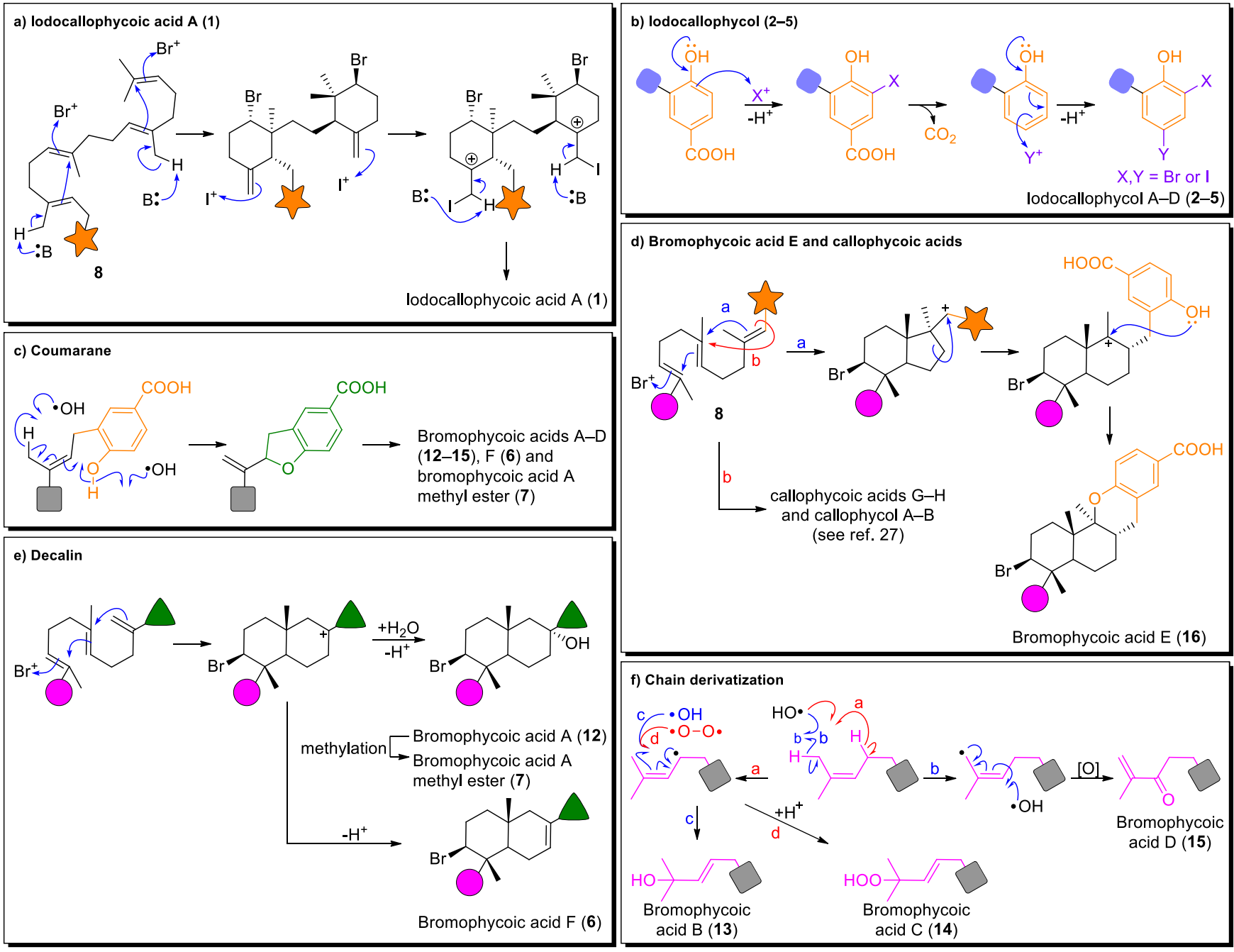

Figure 7. Proposed biosynthetic pathway for meroditerpenes of Callophycus spp. Color code: decalin (

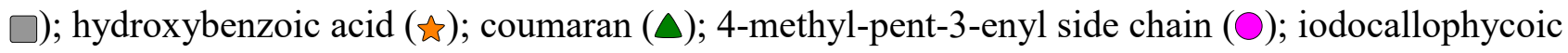
acid A (1) ring system (๑).

The bioactivities of 1-8 against wild type and resistant bacterial strains were evaluated (Table 5). Iodocallophycoic acid A (1) and bromophycoic acid F (6) both showed moderate antibiotic activities against MRSA and VREF with MIC90 values of 1.4-8.0 $\mu \mathrm{g} \mathrm{mL}^{-1}$. Interestingly, the closest analogs of 1, callophycoic acids C-E, did not show any activity against these human pathogens. ${ }^{27}$ The lack of bioactivity of iodocallophycols A-D (2-5) suggested that the carboxylic acid on the phenol ring is crucial to inhibit bacterial growth. The same phenomenon was observed with the bioactive callophycoic acids G- 
$\mathrm{H}$, which possess a hydroxybenzoic acid ring, whereas the inactive callophycols $\mathrm{A}-\mathrm{B}$ have a phenol but not carboxylic acid functional group. ${ }^{27}$ Checkerboard assays were used to evaluate synergistic effects of 1-5 in combination with known antibiotics. When MRSA was exposed to a commercially available antibiotic, oxacillin, in combination with $\mathbf{1}$, sensitization was observed, resulting in an 8-fold drop in MIC for oxacillin (128 to $16 \mu \mathrm{g} \mathrm{mL}^{-1}$ ) and a fractional inhibitory concentration (FIC) index of 0.19 , indicating positive synergy between these antimicrobials. No other combinations yielded a synergistic activity (Table 5 and Supporting Information).

Table 5. Pharmacological activities of $\mathbf{1 - 8}$.

\begin{tabular}{lcccccccc}
\hline Assays & $\mathbf{1}$ & $\mathbf{2}$ & $\mathbf{3}$ & $\mathbf{4}$ & $\mathbf{5}$ & $\mathbf{6}$ & $\mathbf{7}$ & $\mathbf{8}$ \\
\hline MRSA MIC $\left(\mu \mathrm{g} \mathrm{mL}^{-1}\right)^{\mathrm{a}}$ & 1.4 & $>10$ & $>10$ & $>10$ & $>10$ & 8.0 & $>10$ & 1.8 \\
CA-MRSA MIC $\left.(\mu \mathrm{g} \mathrm{mL})^{-1}\right)^{\mathrm{b}}$ & 2 & $>16$ & $>16$ & $>16$ & $>16$ & NT & NT & NT \\
CA-MRSA + oxacillin FIC index & 0.19 & 0.52 & 0.52 & 0.52 & 1.02 & NT & NT & NT \\
VISA MIC $\left(\mu \mathrm{g} \mathrm{mL}^{-1}\right)^{\mathrm{c}}$ & 4 & $>16$ & $>16$ & $>16$ & $>16$ & NT & NT & NT \\
VISA + vancomycin FIC index & 1.02 & $>1.25$ & $>1.25$ & $>1.25$ & $>1.25$ & NT & NT & NT \\
VREF MIC $\left(\mu \mathrm{g} \mathrm{mL}^{-1}\right)^{\mathrm{d}}$ & 2.2 & $>10$ & $>10$ & $>10$ & $>10$ & 1.6 & $>10$ & $>10$ \\
VREF MIC $\left(\mu \mathrm{g} \mathrm{mL}^{-1}\right)^{\mathrm{e}}$ & 2 & $>16$ & $>16$ & $>16$ & $>16$ & NT & NT & NT \\
VREF + vancomycin FCC index & 0.63 & $>1.25$ & $>1.25$ & $>1.25$ & $>1.25$ & NT & NT & NT \\
E. coli MIC $\left(\mu \mathrm{g} \mathrm{mL}^{-1}\right) \mathrm{f}$ & $>10$ & $>10$ & $>10$ & $>10$ & $>10$ & $>10$ & $>10$ & $>10$ \\
MDREC MIC $\left(\mu \mathrm{g} \mathrm{mL}^{-1}\right)^{\mathrm{g}}$ & $>10$ & $>10$ & $>10$ & $>10$ & $>10$ & $>10$ & $>10$ & $>10$ \\
C. albicans $\mathrm{MIC}\left(\mu \mathrm{g} \mathrm{mL}^{-1}\right)^{\mathrm{h}}$ & $>10$ & $>10$ & $>10$ & $>10$ & $>10$ & $>10$ & $>10$ & $>10$ \\
ARCA MIC $\left(\mu \mathrm{gL} \mathrm{m}^{-1}\right)^{\mathrm{i}}$ & $>10$ & $>10$ & $>10$ & $>10$ & $>10$ & $>10$ & $>10$ & $>10$ \\
\hline
\end{tabular}

${ }^{\mathrm{a}}$ methicillin-resistant Staphylococcus aureus (ATCC 33591); ${ }^{\mathrm{b}}$ community-associated methicillin-resistant

S. aureus (strain LAC); 'vancomycin intermediate, methicillin-resistant S. aureus (NR-45858); ${ }^{\mathrm{d}} \mathrm{vancomycin}-\mathrm{resistant}$ Enterococcus faecium (ATCC 700221); ${ }^{\mathrm{e}}$ vancomycin-resistant E. faecium (NR31915); ${ }^{\mathrm{f}}$ Escherichia coli (ATCC 25922); ${ }^{\mathrm{g}}$ multi-drug-resistant E. coli (ATCC BAA-1743); ${ }^{\mathrm{h}}$ wild-type Candida albicans (ATCC 32354); ${ }^{i}$ amphotericin B-resistant C. albicans (ATCC 90873); NT: Not tested.

\section{EXPERIMENTAL DETAILS}

General Experimental Procedures. Optical rotations were recorded in chloroform or methanol at $589 \mathrm{~nm}$. The electronic circular dichroism spectra were recorded in acetonitrile at $25{ }^{\circ} \mathrm{C}$. NMR spectra $\left({ }^{1} \mathrm{H}, \mathrm{HMBC}\right.$, edited-HSQC, DQF-COSY and NOESY) were recorded on a $18.8 \mathrm{~T}\left(800 \mathrm{MHz}\right.$ for ${ }^{1} \mathrm{H}$ and 
$200 \mathrm{MHz}$ for ${ }^{13} \mathrm{C}$ ) instrument equipped with a $5 \mathrm{~mm}$ triple resonance broadband cryoprobe. All spectra were acquired in $\mathrm{CD}_{3} \mathrm{OD}$ and chemical shifts were reported in ppm $(\delta)$ relative to the residual solvent peaks $\left(\delta_{\mathrm{H}} 3.31\right.$ and $\left.\delta_{\mathrm{C}} 49.05\right)$. The NOESY experiment used for distance determination was obtained using a zero-quantum filter. ${ }^{34}$ The mixing time was set to $300 \mathrm{~ms}$. All the spectra were processed using MestReNova 11.0, and the integration of the 1D NOESY slice was done with the help of General Spectral Deconvolution. HPLC fractionations and purifications were performed on a system comprised of a binary pump and a dual-wavelength absorbance detector. The detector was set at $260 \mathrm{~nm}$. Chromatographic

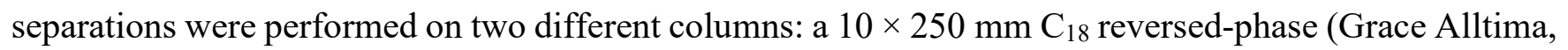
$5 \mu \mathrm{m}$ particule size), and a $4.6 \times 250 \mathrm{~mm}$ Phenyl-Hexyl phase (Phenomenex Luna, $5 \mu \mathrm{m}$ particule size) Low resolution mass spectrometry was used in negative mode to characterize purity and molecular weights of fractions and compounds. High-resolution mass spectrometry was conducted on an Orbitrap spectrometer in negative ion mode.

Specimen Collection. Red algae (collection G-0807) were harvested on April 6th, 2010 between 10 and $20 \mathrm{~m}$ on channel walls and on the reef slope near the Mango Bay Resort, Viti Levu, Fiji (18¹4'12” S, $177^{\circ} 46^{\prime} 48^{\prime}$ E). This collection was identified as Callophycus sp. through a series of 18S rRNA analyses and morphological comparisons as previously described. ${ }^{35}$ Voucher specimens were preserved in aqueous formaldehyde and stored at the University of the South Pacific. The collection was stored at $-80{ }^{\circ} \mathrm{C}$.

Isolation of 1-8. Frozen Callophycus sp. (352.2 g) was thawed at room temperature, broken down into $1 \mathrm{~cm}$ size pieces, and extracted successively with $\mathrm{MeOH}(2 \times 1 \mathrm{~L})$ and $\mathrm{MeOH} / \mathrm{DCM}$ 1:1 $(1 \mathrm{~L})$. The extracts were pooled and concentrated under vacuum to yield $21.7 \mathrm{~g}$ of a dark green gum. The residue was dissolved in $\mathrm{MeOH} / \mathrm{H}_{2} \mathrm{O}$ 9:1 $(735 \mathrm{~mL})$, and partitioned with hexanes $(3 \times 500 \mathrm{~mL})$. Water was added to the $\mathrm{MeOH} / \mathrm{H}_{2} \mathrm{O}$ mixture to make a 3:2 solution which was then partitioned with $\mathrm{DCM}(3 \times 500 \mathrm{~mL})$. All three fractions were concentrated in vacuo yielding fractions A (hexanes, $0.45 \mathrm{~g}$ ), B (DCM, $0.93 \mathrm{~g}$ ), and $\mathrm{C}\left(\mathrm{MeOH} / \mathrm{H}_{2} \mathrm{O}, 20.3 \mathrm{~g}\right)$. After comparison of their HPLC profiles, fractions A and B were pooled prior to 
separation on an ENVI-18 SPE cartridge (10 g, Sigma-Aldrich). The mixture was eluted with $\mathrm{H}_{2} \mathrm{O}$ and $\mathrm{MeOH}(50 \% \rightarrow 100 \%$ step gradient) yielding seven fractions (AB1-AB7). Fraction AB6, eluted at 95\% $\mathrm{MeOH},\left(504.7 \mathrm{mg}\right.$ ) was subjected to HPLC separation on a $\mathrm{C}_{18}$ silica column (Alltima $5 \mu \mathrm{m}, 250 \times$ $10 \mathrm{~mm})$ eluting at $4 \mathrm{~mL} / \mathrm{min}$ with $\mathrm{H}_{2} \mathrm{O}$ and $\mathrm{MeCN}(80 \% \rightarrow 95 \%$ gradient in $15 \mathrm{~min})$. The peaks at 14.5 and 18.8 min were collected (AB6.1 and AB6.2). Fraction AB6.1 was further separated by HPLC with a phenyl-hexyl column (Luna $5 \mu \mathrm{m}, 250 \times 4.6 \mathrm{~mm}$ ), eluted with $\mathrm{H}_{2} \mathrm{O}+0.05 \%$ TFA and $\mathrm{MeCN}(75 \%$ isocratic). Compounds $1\left(\mathrm{R}_{\mathrm{t}}=10.1 \mathrm{~min}, 6.6 \mathrm{mg}\right)$ and $\mathbf{8}\left(\mathrm{R}_{\mathrm{t}}=15.5 \mathrm{~min}, 1.6 \mathrm{mg}\right)$ were obtained as pure compounds. Fraction AB6.2 was also purified using the same phenyl-hexyl column which was eluted with $\mathrm{H}_{2} \mathrm{O}+0.05 \%$ TFA and $\mathrm{MeOH}(90 \%$ isocratic). The peak at 22.0 min was collected and further purified with the same column but with $\mathrm{H}_{2} \mathrm{O}+0.05 \%$ TFA and MeCN (75\% isocratic). Compounds $6(\mathrm{Rt}=$ $17.5 \mathrm{~min}, 1.0 \mathrm{mg})$ and 7 (18.9 min, $1.4 \mathrm{mg})$ were finally obtained as pure compounds. Fraction AB7 was separated on an ENVI-18 SPE cartridge (10 g, Sigma-Aldrich) eluting with a $\mathrm{H}_{2} \mathrm{O}$ and $\mathrm{MeCN}(95 \%$ isocratic). The fractions obtained were analyzed by LCMS and the fraction containing compounds with $m / z>900$ were pooled. The latter was separated by HPLC using the phenyl-hexyl column, eluted with $\mathrm{H}_{2} \mathrm{O}+0.05 \%$ TFA and $\mathrm{MeCN}(85 \% \rightarrow 90 \%$ gradient in $20 \mathrm{~min})$ and compounds $2\left(\mathrm{R}_{\mathrm{t}}=22.7 \mathrm{~min}, 3.8 \mathrm{mg}\right)$ and $5\left(R_{t}=25.4 \mathrm{~min}, 3.0 \mathrm{mg}\right)$ were obtained as pure compounds. The peak eluting at $\mathrm{R}_{\mathrm{t}} 24.0$ min was further purified with the semi-preparative $\mathrm{C} 18$ column eluting with $\mathrm{H}_{2} \mathrm{O}+0.05 \%$ TFA and $\mathrm{MeCN}(93 \%$ isocratic) to obtain pure $3\left(\mathrm{R}_{\mathrm{t}} 36.3 \mathrm{~min}, 1.0 \mathrm{mg}\right)$ and $4(\mathrm{Rt} 37.7 \mathrm{~min}, 1.5 \mathrm{mg})$.

Iodocallophycoic acid $\boldsymbol{A}(1)$ : White amorphous solid; $[\alpha]^{20}{ }_{\mathrm{D}}-56.6\left(c 0.08, \mathrm{CHCl}_{3}\right) ; \mathrm{UV}(\mathrm{MeCN}) \lambda_{\max }(\log$ ع) 212 (4.69), 252 (4.03); $\mathrm{ECD}\left(c 24 \times 10^{-6}, \mathrm{MeCN}\right) \lambda_{\max }(\Delta \varepsilon) 220(-4.9), 255(+5.0), 300(-0.4) ;{ }^{1} \mathrm{H}$ and ${ }^{13} \mathrm{C}$ NMR data, see Tables 1 and 2; HRMS (ESI) $m / z$ : $[\mathrm{M}-\mathrm{H}]^{-}$Calcd for $\mathrm{C}_{27} \mathrm{H}_{33} \mathrm{Br}_{2} \mathrm{I}_{2} \mathrm{O}_{3} 816.8891$; found 816.8859. 
Iodocallophycol $\boldsymbol{A}$ (2): White amorphous solid; $[\alpha]^{20}{ }_{\mathrm{D}}-4.3\left(c 0.25, \mathrm{CHCl}_{3}\right) ; \mathrm{UV}(\mathrm{MeCN}) \lambda_{\max }(\log \varepsilon) 204$ (4.63), 286 (3.22); $\mathrm{ECD}\left(c 20 \times 10^{-6}, \mathrm{MeCN}\right) \lambda_{\max }(\Delta \varepsilon) 232(-1.8), 252(-4.1), 291(-0.7) ;{ }^{1} \mathrm{H}$ and ${ }^{13} \mathrm{C}$ NMR, see Tables 1 and 2; HRMS (ESI) $m / z$ : [M - H] $]^{-}$Calcd for $\mathrm{C}_{26} \mathrm{H}_{31} \mathrm{Br}_{4} \mathrm{I}_{2} \mathrm{O}$ 928.7203; found 928.7211.

Iodocallophycol B (3) White amorphous solid; $[\alpha]^{20} \mathrm{D}-53.9\left(c 0.20, \mathrm{CHCl}_{3}\right) ; \mathrm{UV}(\mathrm{MeCN}) \lambda_{\max }(\log \varepsilon) 212$ (4.86), 286 (3.57); $\mathrm{ECD}\left(c 20 \times 10^{-6}, \mathrm{MeCN}\right) \lambda_{\max }(\Delta \varepsilon) 229(+8.2), 258(+0.2), 291(+2.3) ;{ }^{1} \mathrm{H}$ and ${ }^{13} \mathrm{C}$ NMR data, see Tables 1 and 2; HRMS (ESI) m/z: [M - H] $]^{-}$Calcd for $\mathrm{C}_{26} \mathrm{H}_{31} \mathrm{Br}_{3} \mathrm{I}_{3} \mathrm{O} 976.7065$; found 976.7063.

Iodocallophycol C (4) White amorphous solid; $[\alpha]^{20} \mathrm{D}-53.2\left(c 0.06, \mathrm{CHCl}_{3}\right) ; \mathrm{UV}(\mathrm{MeCN}) \lambda_{\max }(\log \varepsilon) 208$ (4.91), 281 (3.49); $\mathrm{ECD}\left(c 20 \times 10^{-6}, \mathrm{MeCN}\right) \lambda_{\max }(\Delta \varepsilon) 229(+3.6), 254(-2.4), 295(-0.1), 311(-0.8) ;{ }^{1} \mathrm{H}$ and ${ }^{13} \mathrm{C}$ NMR data, see Tables 1 and 2; HRMS (ESI) $m / z$ : $[\mathrm{M}-\mathrm{H}]^{-}$Calcd for $\mathrm{C}_{26} \mathrm{H}_{31} \mathrm{Br}_{3} \mathrm{I}_{3} \mathrm{O} 976.7065$; found 976.7062 .

Iodocallophycol D (5) White amorphous solid; $[\alpha]^{20} \mathrm{D}-91.4\left(c 0.10, \mathrm{CHCl}_{3}\right) ; \mathrm{UV}(\mathrm{MeCN}) \lambda_{\max }(\log \varepsilon) 217$ (4.70), 286 (3.39); $\operatorname{ECD}\left(c 20 \times 10^{-6}, \mathrm{MeCN}\right) \lambda_{\max }(\Delta \varepsilon) 208(-13.3), 231(+7.4), 256(-0.5), 292(+1.3)$; ${ }^{1} \mathrm{H}$ and ${ }^{13} \mathrm{C}$ NMR data, see Tables 1 and 2; HRMS (ESI) $m / z$ : $[\mathrm{M}-\mathrm{H}]-$ Calcd for $\mathrm{C}_{26} \mathrm{H}_{31} \mathrm{Br}_{2} \mathrm{I}_{4} \mathrm{O}$ 1024.6926; found 1024.6926.

Bromophycoic acid F (6): White amorphous solid; $[\alpha]^{27}{ }_{\mathrm{D}}-696(c 0.004, \mathrm{MeOH}) ; \mathrm{UV}(\mathrm{MeCN}) \lambda_{\max }(\log$ ع) 262 (4.2); $\mathrm{ECD}\left(c 37 \times 10^{-6}, \mathrm{MeCN}\right) \lambda_{\max }(\Delta \varepsilon) 221(-4.3), 268(+8.0) ;{ }^{1} \mathrm{H}$ and ${ }^{13} \mathrm{C}$ NMR data, see Table 4; HRMS (ESI) m/z: [M - H] $]^{-}$Calcd for $\mathrm{C}_{27} \mathrm{H}_{34} \mathrm{BrO}_{3}$ 485.1697; found 485.1686.

Bromophycoic acid $\boldsymbol{A}$ methyl ester (7): White amorphous solid; $[\alpha]^{27}-737$ (c $\left.0.005, \mathrm{MeOH}\right)$; UV $(\mathrm{MeCN}) \lambda_{\max }(\log \varepsilon) 262(4.1) ; \mathrm{ECD}\left(c 34 \times 10^{-6}, \mathrm{MeCN}\right) \lambda_{\max }(\Delta \varepsilon) 223(-4.1), 267(+4.1), 317(-1.1) ;{ }^{1} \mathrm{H}$ and ${ }^{13} \mathrm{C}$ NMR data, see Table 4; HRMS (ESI) $m / z$ : $[\mathrm{M}-\mathrm{H}]^{-}$Calcd for $\mathrm{C}_{28} \mathrm{H}_{38} \mathrm{BrO}_{4}$ 517.1959; found 517.1951. 
Computational methods. Compounds 1, 6 and 7 were subjected to quantum-chemical calculation in order to determine their relative and absolute configurations. Firstly, 3D models were generated on $\operatorname{Spartan}^{36}$ with hypothetical configuration being either $2 S, 6 S, 7 S, 12 S, 16 S$ or $2 S, 6 S, 7 S, 12 R, 16 R$ for iodocallophycoic acid A (1), 6S,9R,12S,13S,24R for bromophycoic acid F (6), and 6S,7R,9R,12S,13S,24R for bromophycoic acid A methyl ester (7). A conformer search was done with these models using MMFF94 force field and Monte-Carlo algorithm. All conformers below a cutoff of $21 \mathrm{~kJ} \mathrm{~mol}^{-1}$ in relative energy were then subjected to a geometrical optimization with the help of Gaussian D09 package. The density of functional theory (DFT) was used at the B3LYP/SVP level of theory, and the interaction with the solvent was taken into account with the polarizable continuum model (IEF-PCM, solvent was either methanol for distances calculation, or acetonitrile for ECD prediction). The calculation of the frequencies was carried out in order to derive the thermochemical parameters and to confirm that true minima were obtained (zero imaginary frequency). The values of free energies were extracted to compute the Boltzmann distribution, which were then used to weight the distances and the ECD spectra of the equilibrium conformers. The relevant distances for each conformer were extracted and weighted using the following formula:

$$
d_{\text {weighted }}=\left(\frac{\sum\left(d_{i}^{-6} \times w_{i}\right)}{\sum w_{i}}\right)^{-1 / 6}
$$

The ECD spectra were predicted with time-dependent DFT at the B3LYP/SVP level of theory. The resulting excitation energies and rotatory strength were used as argument of a custom function script in spreadsheet program which is based on the following equation in order to simulate the ECD curves:

$$
\Delta \varepsilon(E)=\frac{1}{2.297 \times 10^{-39} \sqrt{2 \pi \sigma}} \sum_{i} \Delta E_{i} R_{i} e^{-\left[\left(E-E_{i}\right) / 2 \sigma\right]^{2}}
$$

A bandwidth $(\sigma)$ of $0.25 \mathrm{eV}$ was used for all the spectra. 
Small-scale extraction and LCMS analysis. Two samples of frozen Callophycus sp. $(2 \times 10 \mathrm{~g})$ were thawed at room temperature and extracted in parallel with $\mathrm{MeOH}$ or $\mathrm{EtOH}$ (each $100 \mathrm{~mL}$ ), then with $\mathrm{MeOH} / \mathrm{DCM}$ 1:1 or EtOH/DCM 1:1 (both $100 \mathrm{~mL}$ ). The extracts were concentrated under vacuum to yield 434 and $352 \mathrm{mg}$ of extract, for $\mathrm{MeOH}$ and $\mathrm{EtOH}$ respectively. The residues were separated on an ENVI-18 SPE cartridge (10 g), rinsed with aqueous MeCN 50\%, and the non-polar compounds were recovered using $\mathrm{MeCN}$ 100\%. The solvent was evaporated and the samples were reconstituted in $\mathrm{MeCN}$ at a concentration of $10 \mathrm{mg} / \mathrm{mL}$. LCMS analyses were conducted with a $\mathrm{C}_{18}$ column $(50 \times 2.1 \mathrm{~mm}, 5 \mu \mathrm{m})$ eluted isocratically at $0.2 \mathrm{~mL} / \mathrm{min}$ with $70 \% \mathrm{MeCN}$ and $30 \% \mathrm{H}_{2} \mathrm{O}+0.1 \% \mathrm{HCOOH}$. Since negative mode MS was not sensitive enough to detect bromophycoic acid A methyl ester (7), the positive mode was preferred. The base peak $\left[\mathrm{M}+\mathrm{H}-\mathrm{H}_{2} \mathrm{O}\right]^{+}$at $m / z$ 501, along with the hypothetical ethyl ester corresponding ion at $m / z 515$, were monitored to confirm the presence of these putative compounds in the extracts.

Pharmacological assay. Antibacterial and antifungal assays were performed as previously described ${ }^{33}$ using methicillin-resistant Staphylococcus aureus (MRSA, ATCC 33591), Vancomycin-resistant Enterococcus faecium (VREF, ATCC 700221), Escherichia coli (EC, ATCC 25922), Multi-drug-resistant Escherichia coli (MDREC, ATCC BAA-1743), Wild type Candida albicans (WTCA, ATCC 32354), and Amphotericin B-resistant Candida albicans (ARCA, ATCC 90873) as pathogens. The positive controls used were vancomycin for MRSA, chloramphenicol for VREF and EC, nitrofurantoin for MDREC, amphotericin B for WTCA and cycloheximide for ARCA.

Additional testing for potential synergistic activity was performed by checkerboard assay in combination with either oxacillin or vancomycin as previously described ${ }^{37}$ using community associated CA-MRSA (strain LAC), vancomycin intermediate MRSA (VISA, NR-45858), and VREF (NR-31915). The fractional inhibitory concentration index (FIC index), calculated using equation 3, was interpreted as synergy (FIC index $\leq 0.5)$, antagonism (FIC index $\geq 4.0$ ) and no interaction (FIC index $0.5-4.0) .{ }^{38}$ 


$$
F I C \text { index }=\frac{C_{o x}}{M I C_{o x}}+\frac{C_{c m p d}}{M I C_{c m p d}}
$$

where $M I C$ is the minimal inhibitory concentration for the drug alone and $C$ is the MIC for the drug in presence of the co-drug.

\section{ACKNOWLEDGMENTS}

This work was supported by ICBG Grant U19-TW007401 from the U.S. National Institutes of Health. The authors thank the Government of Fiji and the customary fishing right owners for permission to perform research in their territorial waters, and M.E. Hay and W. Aalsberberg for management of the project. We thank M.E. Hay, D. Rasher, K. Soape, and K. Feussner for collection of algal samples; D.E Bostwick and C. Sullards for mass spectrometric analyses; L.T. Gelbaum for NMR assistance; N.V. Hud and S. Karunakaran for ECD spectroscopy measurement; J. Mathew-Valayil, K. Syhapanha, and S. Engel for antimicrobial assays; and A.M. Sweeney-Jones for comments to improve the manuscript. Staphylococcus aureus, Strain HIP5827, NR-45858 was provided by the Network on Antimicrobial Resistance in Staphylococcus aureus (NARSA) for distribution by BEI Resources, NIAID, NIH. Enterococcus faecium, Strain E0164, NR-31915 was obtained through BEI Resources, NIAID, NIH as part of the Human Microbiome Project. We are especially appreciative of the leadership of the Georgia Institute of Technology for investing in new NMR capabilities in 2016, making this research possible.

\section{SUPPORTING INFORMATION}

DFT energies and geometries of compounds 1, 6 and 7, and spectroscopic data for compounds 1-7 (PDF)

Microdilution checkerboard analysis showing the combined effect of compounds 1-5 and oxacillin against CA-MRSA USA300; and compounds 1-5 with vancomycin against VISA and VREF, where the extent of inhibition is shown as a heat plot (PDF). 


\section{REFERENCES}

1. Gribble, G. W., The diversity of naturally produced organohalogens. In Handbook of Environmental Chemistry Springer Verlag2003; Vol. 3, pp 1-15.

2. MarinLit: A Database of the Marine Natural Products Literature. Royal Society of Chemistry: London, 2016.

3. Butler, A.; Walker, J. V. Chem. Rev. 1993, 93, 1937-1944.

4. Leblanc, C.; Colin, C.; Cosse, A.; Delage, L.; La Barre, S.; Morin, P.; Fiévet, B.; Voiseux, C.; Ambroise, Y.; Verhaeghe, E.; Amouroux, D.; Donard, O.; Tessier, E.; Potin, P. Biochimie 2006, 88, 1773-1785.

5. Butler, A.; Sandy, M. Nature 2009, 460, 848-854.

6. CRC handbook of chemistry and physics. CRC Press: Cleveland, Ohio, 2005; pp 8-23-8-28.

7. McConnell, O.; Fenical, W. Phytochemistry 1977, 16, 367-374.

8. Jacobsen, N.; Madsen, J. Ø. Tetrahedron Lett. 1978, 19, 3065-3068.

9. Siuda, J. F.; VanBlaricom, G. R.; Shaw, P. D.; Johnson, R. D.; White, R. H.; Hager, L. P.; Rinehart Jr, K. L. J. Am. Chem. Soc. 1975, 97, 937-938.

10. Rose, A. F.; Pettus Jr, J. A.; Sims, J. J. Tetrahedron Lett. 1977, 18, 1847-1850.

11. Woolard, F. X.; Moore, R. E.; Roller, P. P. Phytochemistry 1979, 18, 617-620.

12. Woolard, F. X.; Moore, R. E.; Roller, P. P. Tetrahedron 1976, 32, 2843-2846.

13. Kazlauskas, R.; Murphy, P. T.; Quinn, R. J.; Wells, R. J. Tetrahedron Lett. 1977, 18, 37-40.

14. de Nys, R.; Wright, A. D.; König, G. M.; Sticher, O. Tetrahedron 1993, 49, 11213-11220.

15. Woolner, V. H.; Jones, C. M.; Field, J. J.; Fadzilah, N. H.; Munkacsi, A. B.; Miller, J. H.; Keyzers, R. A.; Northcote, P. T. J. Nat. Prod. 2016, 79, 463-469.

16. Izac, R. R.; Sims, J. J. J. Am. Chem. Soc. 1979, 101, 6136-6137.

17. Kladi, M.; Vagias, C.; Papazafiri, P.; Furnari, G.; Serio, D.; Roussis, V. Tetrahedron 2007, 63, 76067611.

18. Williams, P. G.; Yoshida, W. Y.; Moore, R. E.; Paul, V. J. Org. Lett. 2003, 5, 4167-4170.

19. Teasdale, M. E.; Shearer, T. L.; Engel, S.; Alexander, T. S.; Fairchild, C. R.; Prudhomme, J.; Torres, M.; Le Roch, K.; Aalbersberg, W.; Hay, M. E.; Kubanek, J. J. Org. Chem. 2012, 77, 8000-8006.

20. Petraki, A.; Ioannou, E.; Papazafiri, P.; Roussis, V. J. Nat. Prod. 2015, 78, 462-467.

21. Kim, H.; Chin, J.; Choi, H.; Baek, K.; Lee, T. G.; Park, S. E.; Wang, W.; Hahn, D.; Yang, I.; Lee, J.; Mun, B.; Ekins, M.; Nam, S. J.; Kang, H. Org. Lett. 2013, 15, 100-103.

22. Nothias-Scaglia, L.-F.; Gallard, J.-F.; Dumontet, V.; Roussi, F.; Costa, J.; Iorga, B. I.; Paolini, J.; Litaudon, M. J. Nat. Prod. 2015, 78, 2423-2431.

23. Lavoie, S.; Gauthier, C.; Mshvildadze, V.; Legault, J.; Roger, B.; Pichette, A. J. Nat. Prod. 2015, 78, 2896-2907.

24. Di Micco, S.; Zampella, A.; D'Auria, M. V.; Festa, C.; De Marino, S.; Riccio, R.; Butts, C. P.; Bifulco, G. Beilstein J. Org. Chem. 2013, 9, 2940-2949.

25. Frisch, M. J.; Trucks, G. W.; Schlegel, H. B.; Scuseria, G. E.; Robb, M. A.; Cheeseman, J. R.; Scalmani, G.; Barone, V.; Mennucci, B.; Petersson, G. A.; Nakatsuji, H.; Caricato, M.; Li, X.; Hratchian, H. P.; Izmaylov, A. F.; Bloino, J.; Zheng, G.; Sonnenberg, J. L.; Hada, M.; Ehara, M.; Toyota, K.; Fukuda, R.; Hasegawa, J.; Ishida, M.; Nakajima, T.; Honda, Y.; Kitao, O.; Nakai, H.; Vreven, T.; Jr., J. A. M.; Peralta, J. E.; Ogliaro, F.; Bearpark, M.; Heyd, J. J.; Brothers, E.; Kudin, K. N.; Staroverov, V. N.; Keith, T.; Kobayashi, R.; Normand, J.; Raghavachari, K.; Rendell, A.; Burant, J. C.; Iyengar, S. S.; Tomasi, J.; Cossi, M.; Rega, N.; Millam, J. M.; Klene, M.; Knox, J. E.; Cross, J. B.; Bakken, V.; Adamo, C.; Jaramillo, J.; Gomperts, R.; Stratmann, R. E.; Yazyev, O.; Austin, A. J.; Cammi, R.; Pomelli, C.; Ochterski, J. W.; Martin, R. L.; Morokuma, K.; Zakrzewski, V. G.; Voth, G. 
A.; Salvador, P.; Dannenberg, J. J.; Dapprich, S.; Daniels, A. D.; Farkas, O.; Foresman, J. B.; Ortiz, J. V.; Cioslowski, J.; Fox, D. J. Gaussian 09, Revision D.01: Wallingford CT (USA), 2013.

26. Jones, C. R.; Butts, C. P.; Harvey, J. N. Beilstein J. Org. Chem. 2011, 7, 145-150.

27. Lane, A. L.; Stout, E. P.; Hay, M. E.; Prusak, A. C.; Hardcastle, K.; Fairchild, C. R.; Franzblau, S. G.; Le Roch, K.; Prudhomme, J.; Aalbersberg, W.; Kubanek, J. J. Org. Chem. 2007, 72, 7343-7351.

28. Matsuda, Y.; Awakawa, T.; Itoh, T.; Wakimoto, T.; Kushiro, T.; Fujii, I.; Ebizuka, Y.; Abe, I. ChemBioChem 2012, 13, 1738-1741.

29. Rajniak, J.; Barco, B.; Clay, N. K.; Sattely, E. S. Nature 2015, 525, 376-379.

30. Brondz, I.; Ekeberg, D.; Høiland, K.; Bell, D. S.; Annino, A. R. J. Chromatogr. A 2007, 1148, 1-7.

31. Jauffrais, T.; Herrenknecht, C.; Séchet, V.; Sibat, M.; Tillmann, U.; Krock, B.; Kilcoyne, J.; Miles, C. O.; McCarron, P.; Amzil, Z.; Hess, P. Anal. Bioanal. Chem. 2012, 403, 833-846.

32. López-Ogalla, J.; García-Palomero, E.; Sánchez-Quesada, J.; Rubio, L.; Delgado, E.; García, P.; Medina, M.; Castro, A.; Muñoz, P. MedChemComm 2014, 5, 474-488.

33. Kubanek, J.; Prusak, A. C.; Snell, T. W.; Giese, R. A.; Hardcastle, K. I.; Fairchild, C. R.; Aalbersberg, W.; Raventos-Suarez, C.; Hay, M. E. Org. Lett. 2005, 7, 5261-5264.

34. Thrippleton, M. J.; Keeler, J. Angew. Chem., Int. Ed. 2003, 42, 3938-3941.

35. Littler, D. S.; Littler, M. M., South Pacific Reef Plants: A Divers' Guide to the Plant Life of South Pacific Coral Reefs. OffShore Graphic, Inc.: Washington, D.C., 2003; p 332.

36. Spartan'10: Irvine, CA 92612 (USA).

37. Farha, M. A.; Leung, A.; Sewell, E. W.; D'Elia, M. A.; Allison, S. E.; Ejim, L.; Pereira, P. M.; Pinho, M. G.; Wright, G. D.; Brown, E. D. ACS Chem. Biol. 2013, 8, 226-233.

38. Odds, F. C. J. Antimicrob. Chemother. 2003, 52, 1. 